4

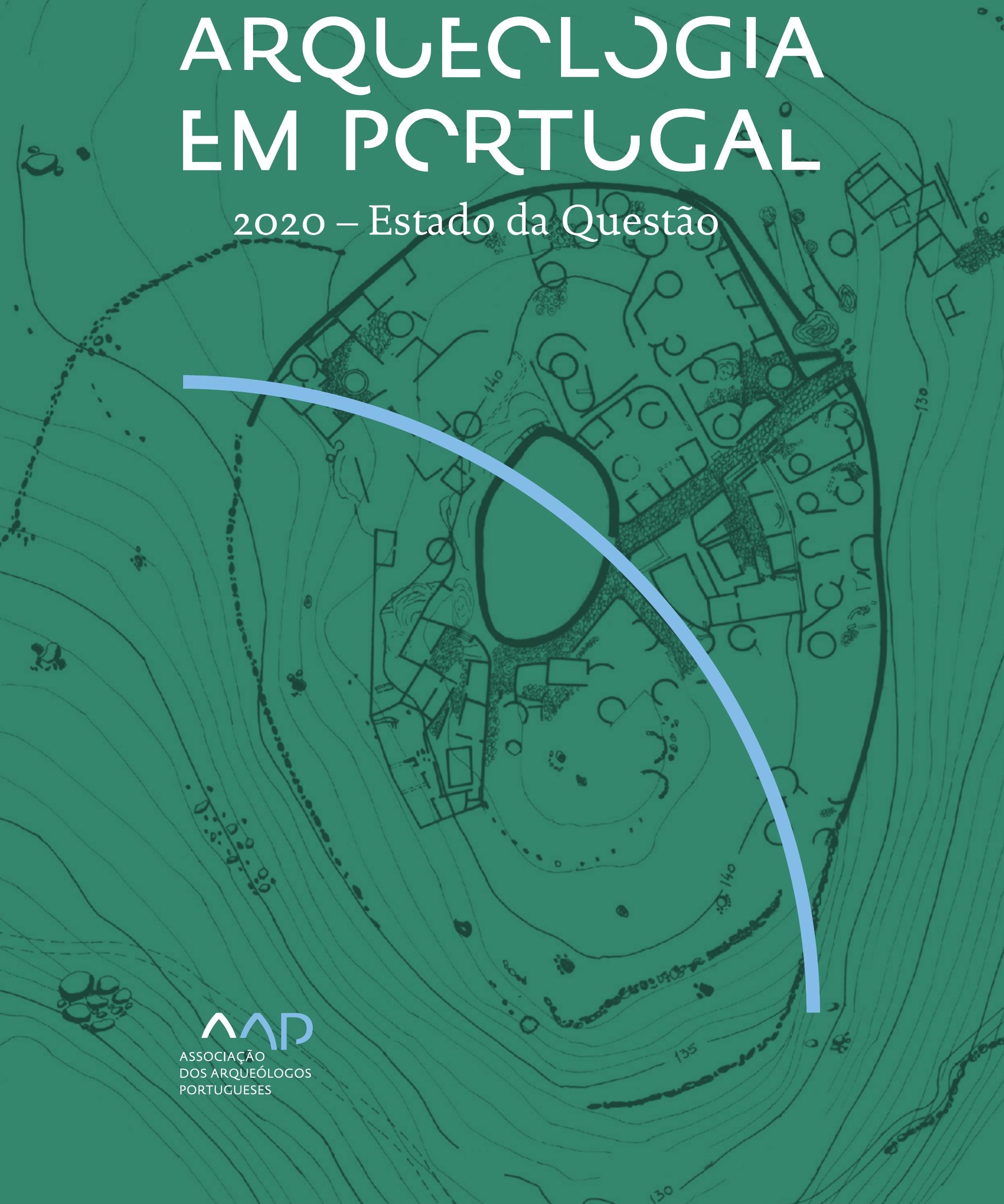


Coordenação editorial: José Morais Arnaud, César Neves e Andrea Martins Design gráfico: Flatland Design

AAP - ISBN: 978-972-9451-89-8

CITCEM - ISBN: 978-989-8970-25-1

Associação dos Arqueólogos Portugueses e CITCEM

Lisboa, 2020

O conteúdo dos artigos é da inteira responsabilidade dos autores. Sendo assim a Associação dos Arqueólogos Portugueses declina qualquer responsabilidade por eventuais equívocos ou questões de ordem ética e legal.

Desenho de capa:

Planta do castro de Monte Mozinho (Museu Municipal de Penafiel).

\section{$\hat{\wedge} \mathrm{P}$}

DOS ARQUEÓLOGOS PORTUGUESES

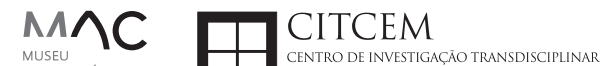
MUSEU
ARQUELLÓGICO
DO CARMO
U.PORTO

FLUP FACULDADE DE LETRAS
UNIVERSIDADE DO PORTO

Apoio

EC para a Ciência 


\section{Índice}

15 Prefácio

José Morais Arnaud

\section{Historiografia e Teoria}

17 Território, comunidade, memória e emoção: a contribuição da história da arqueologia (algumas primeiras e breves reflexões)

Ana Cristina Martins

25 Como descolonizar a arqueologia portuguesa?

Rui Gomes Coelho

41 Arqueologia e Modernidade: uma revisitação pessoal e breve de alguns aspetos da obra homónima de Julian Thomas de 2004

Vítor Oliveira Jorge

57 Dados para a História das Mulheres na Arqueologia portuguesa, dos finais do século XIX aos inícios do século XX: números, nomes e tabelas

Filipa Dimas / Mariana Diniz

73 Retractos da arqueologia portuguesa na imprensa: (in)visibilidades no feminino

Catarina Costeira / Elsa Luís

85 Arqueologia e Arqueólogos no Norte de Portugal Jacinta Bugalhão

101 Vieira Guimarães (1864-1939) e a arqueologia em Tomar: uma abordagem sobre o território e as gentes

João Amendoeira Peixoto / Ana Cristina Martins

115 Os memoráveis? A arqueologia algarvia na imprensa nacional e regional na presente centúria (2001-2019): características, visões do(s) passado(s) e a arqueologia

enquanto marca

Frederico Agosto / João Silva

129 A Evolução da Arqueologia Urbana e a Valorização Patrimonial no Barlavento Algarvio: Os casos de Portimão e Silves

Artur Mateus / Diogo Varandas / Rafael Boavida

\section{Gestão, Valorização e Salvaguarda do Património}

145 O Caderno Reivindicativo e as condições de trabalho em Arqueologia Miguel Rocha / Liliana Matias Carvalho / Regis Barbosa / Mauro Correia / Sara Simões / Jacinta Bugalhão / Sara Brito / Liliana Veríssimo Carvalho / Richard Peace / Pedro Peça / Cézer Santos

155 Os Estudos de Impacte Patrimonial como elemento para uma estratégia sustentável de minimização de impactes no âmbito de reconversões agrícolas Tiago do Pereiro

165 Salvaguarda de Património arqueológico em operações florestais: gestão e sensibilização Filipa Bragança / Gertrudes Zambujo / Sandra Lourenço / Belém Paiva / Carlos Banha / Frederico Tatá Regala / Helena Moura / Jacinta Bugalhão / João Marques / José Correia / Pedro Faria / Samuel Melro

179 Os valores do Património: uma investigação sobre os Sítios Pré-históricos de Arte Rupestre do Vale do Rio Côa e de Siega Verde José Paulo Francisco 
189 Conjugando recursos arqueológicos e naturais para potenciar as visitas ao Geoparque Litoral de Viana do Castelo (Noroeste de Portugal)

Hugo A. Sampaio / Ana M.S. Bettencourt / Susana Marinho / Ricardo Carvalhido

203 Áreas de Potencial Arqueológico na Região do Médio Tejo: Modelo Espacial Preditivo Rita Ferreira Anastácio / Ana Filipa Martins / Luiz Oosterbeek

223 Património Arqueológico e Gestão Territorial: O contributo da Arqueologia para a revisão do PDM de Avis

Ana Cristina Ribeiro

237 A coleção arqueológica do extinto Museu Municipal do Porto - Origens, Percursos e Estudos

Sónia Couto

251 Valpaços - uma nova carta arqueológica

Pedro Pereira / Maria de Fátima Casares Machado

263 Arqueologia na Cidade de Peniche

Adriano Constantino / Luís Rendeiro

273 Arqueologia Urbana: a cidade de Lagos como caso de Estudo Cátia Neto

285 Estratégias de promoção do património cultural subaquático nos Açores. O caso da ilha do Faial

José Luís Neto / José Bettencourt / Luís Borges / Pedro Parreira

297 Carta Arqueológica da Cidade Velha: Uma primeira abordagem

Jaylson Monteiro / Nireide Tavares / Sara da Veiga / Claudino Ramos / Edson Brito /

Carlos Carvalho / Francisco Moreira / Adalberto Tavares

311 Antropologia Virtual: novas metodologias para a análise morfológica e funcional Ricardo Miguel Godinho / Célia Gonçalves

\section{Didáctica da Arqueologia}

327 Como os projetos de Arqueologia podem contribuir para uma comunidade culturalmente mais consciente Alexandra Figueiredo / Claúdio Monteiro / Adolfo Silveira / Ricardo Lopes

337 Educação Patrimonial - Um cidadão esclarecido é um cidadão ativo! Ana Paula Almeida

351 A aproximação da Arqueologia à sala de aula: um caso de estudo no $3^{\circ}$ ciclo do Ensino Básico Luís Serrão Gil

363 Arqueologia 3.o - Pensar e comunicar a Arqueologia para um futuro sustentável Mónica Rolo

377 “Conversa de Arqueólogos" - Divulgar a Arqueologia em tempos de Pandemia Diogo Teixeira Dias

389 Escola Profissional de Arqueologia: desafios e oportunidades Susana Nunes / Dulcineia Pinto / Júlia Silva / Ana Mascarenhas

399 Os Museus de Arqueologia e os Jovens: a oferta educativa para o público adolescente Beatriz Correia Barata / Leonor Medeiros

411 O museu universitário como mediador entre a ciência e a sociedade: o exemplo da secção de arqueologia no Museu de História Natural e da Ciência da Universidade do Porto (MHNC-UP)

Rita Gaspar 
421 Museu de Lanifícios: Real Fábrica de Panos. Atividades no âmbito da Arqueologia Beatriz Correia Barata / Rita Salvado

427 Arqueologia Pública e o caso da localidade da Mata (Torres Novas) Cláudia Manso / Ana Rita Ferreira / Cristiana Ferreira / Vanessa Cardoso Antunes

431 Do sítio arqueológico ao museu: um percurso (também) didático Lídia Fernandes

447 Estão todos convidados para a Festa! E para dançar também... O projecto do Serviço Educativo do Museu Arqueológico do Carmo na $5^{\underline{a}}$ Edição da Festa da Arqueologia Rita Pires dos Santos

459 O “Clã de Carenque”, um projeto didático de arqueologia Eduardo Gonzalez Rocha

469 Mediação cultural: peixe que puxa carroça nas Ruínas Romanas de Troia Inês Vaz Pinto / Ana Patrícia Magalhães / Patrícia Brum / Filipa Santos

481 Didática Arqueológica, experiências do Projeto Mértola Vila Museu Maria de Fátima Palma / Clara Rodrigues / Susana Gómez / Lígia Rafael

\section{Arte Rupestre}

497 Os inventários de arte rupestre em Portugal Mila Simões de Abreu

513 O projeto FIRST-ART - conservação, documentação e gestão das primeiras manifestações de arte rupestre no Sudoeste da Península Ibérica: as grutas do Escoural e Maltravieso Sara Garcês / Hipólito Collado / José Julio García Arranz / Luiz Oosterbeek / António Carlos Silva / Pierluigi Rosina / Hugo Gomes / Anabela Borralheiro Pereira / George Nash / Esmeralda Gomes / Nelson Almeida / Carlos Carpetudo

523 Trabalhos de documentação de arte paleolítica realizados no âmbito do projeto PalæoCôa André Tomás Santos / António Fernando Barbosa / Luís Luís / Marcelo Silvestre / Thierry Aubry

537 Imagens fantasmagóricas, silhuetas elusivas: as figuras humanas na arte do Paleolítico Superior da região do Côa Mário Reis

$55^{1}$ Os motivos zoomórficos representados nas placas de tear de Vila Nova de São Pedro (Azambuja, Portugal) Andrea Martins / César Neves / José M. Arnaud / Mariana Diniz

571 Arte Rupestre do Monte de Góios (Lanhelas, Caminha). Síntese dos resultados dos trabalhos efectuados em 2007-2009 Mário Varela Gomes

599 Gravuras rupestres de barquiformes no Monte de S. Romão, Guimarães, Noroeste de Portugal Daniela Cardoso

613 Círculos segmentados gravados na Bacia do Rio Lima (Noroeste de Portugal): contributos para o seu estudo Diogo Marinho / Ana M.S. Bettencourt / Hugo Aluai Sampaio

631 Equídeos gravados no curso inferior do Rio Mouro, Monção (NW Portugal). Análise preliminar Coutinho, L.M. / Bettencourt, A.M.S / Sampaio, Hugo A.S

645 Paletas na Arte Rupestre do Noroeste de Portugal. Inventário preliminar Bruna Sousa Afonso / Ana M. S. Bettencourt / Hugo A. Sampaio 


\section{Pré-História}

661 O projeto Miño/Minho: balanço de quatro anos de trabalhos arqueológicos Sérgio Monteiro-Rodrigues / João Pedro Cunha-Ribeiro / Eduardo Méndez-Quintas / Carlos Ferreira / Pedro Xavier / José Meireles / Alberto Gomes / Manuel Santonja / Alfredo Pérez-González

677 A ocupação paleolítica da margem esquerda do Baixo Minho: a indústria lítica do sítio de Pedreiras 2 (Monção, Portugal) e a sua integração no contexto regional Carlos Ferreira / João Pedro Cunha-Ribeiro / Sérgio Monteiro-Rodrigues / Eduardo Méndez-Quintas / Pedro Xavier / José Meireles / Alberto Gomes / Manuel Santonja / Alfredo Pérez-González

693 O sítio acheulense do Plistocénico médio da Gruta da Aroeira Joan Daura / Montserrat Sanz / Filipa Rodrigues / Pedro Souto / João Zilhão

703 As sociedades neandertais no Barlavento algarvio: modelos preditivos com recurso aos SIG

Daniela Maio

715 A utilização de quartzo durante o Paleolítico Superior no território dos vales dos rios Vouga e Côa

Cristina Gameiro / Thierry Aubry / Bárbara Costa / Sérgio Gomes / Luís Luís / Carmen Manzano / André Tomás Santos

733 Uma perspetiva diacrónica da ocupação do concheiro do Cabeço da Amoreira (Muge, Portugal) a partir da tecnologia lítica Joana Belmiro / João Cascalheira / Célia Gonçalves

745 Novos dados sobre a Pré-história Antiga no concelho de Palmela. A intervenção arqueológica no sítio do Poceirão I

Michelle Teixeira Santos

757 Problemas em torno de Datas Absolutas Pré-Históricas no Norte do Alentejo Jorge de Oliveira

771 Povoamento pré-histórico nas áreas montanhosas do NO de Portugal: o Abrigo 1 de Vale de Cerdeira Pedro Xavier / José Meireles / Carlos Alves

783 Apreciação do povoamento do Neolítico Inicial na Baixa Bacia do Douro. A Lavra I (Serra da Aboboreira) como caso de estudo Maria de Jesus Sanches

797 O Processo de Neolitização na Plataforma do Mondego: os dados do Sector C do Outeiro dos Castelos de Beijós (Carregal do Sal)

João Carlos de Senna-Martinez / José Manuel Quintã Ventura / Andreia Carvalho / Cíntia Maurício

823 Novos trabalhos na Lapa da Bugalheira (Almonda, Torres Novas) Filipa Rodrigues / Pedro Souto / Artur Ferreira / Alexandre Varanda / Luís Gomes / Helena Gomes / João Zilhão

837 A pedra polida e afeiçoada do sítio do Neolítico médio da Moita do Ourives (Benavente, Portugal)

César Neves

857 Casal do Outeiro (Encarnação, Mafra): novos contributos para o conhecimento do povoamento do Neolítico final na Península de Lisboa.

Cátia Delicado / Carlos Maneira e Costa / Marta Miranda / Ana Catarina Sousa

873 Stresse infantil, morbilidade e mortalidade no sítio arqueológico do Neolítico Final/ Calcolítico ( $4^{\circ}$ e $3^{\circ}$ milénio a.C.) do Monte do Carrascal 2 (Ferreira do Alentejo, Beja) Liliana Matias de Carvalho / Sofia N. Wasterlain 
885 Come together: O Conjunto Megalítico das Motas (Monção, Viana do Castelo) e as expressões Campaniformes do Alto Minho Ana Catarina Basílio / Rui Ramos

899 Trabalhos arqueológicos no sítio Calcolítico da Pedreira do Poio Carla Magalhães / João Muralha / Mário Reis / António Batarda Fernandes

913 O sítio arqueológico de Castanheiro do Vento. Da arquitectura do sítio à arquitectura de um território João Muralha Cardoso

925 Estudo zooarqueológico das faunas do Calcolítico final de Vila Nova de São Pedro (Azambuja, Portugal): Campanhas de 2017 e 2018 Cleia Detry / Ana Catarina Francisco / Mariana Diniz / Andrea Martins / César Neves / José Morais Arnaud

943 As faunas depositadas no Museu Arqueológico do Carmo provenientes de Vila Nova de São Pedro (Azambuja): as campanhas de 1937 a 1967 Ana Catarina Francisco / Cleia Detry / César Neves / Andrea Martins / Mariana Diniz / José Morais Arnaud

959 Análise funcional de material lítico em sílex do castro de Vila Nova de S. Pedro (Azambuja, Portugal): uma primeira abordagem Rafael Lima

971 O recinto da Folha do Ouro 1 (Serpa) no contexto dos recintos de fossos calcolíticos alentejanos

António Carlos Valera / Tiago do Pereiro / Pedro Valério / António M. Monge Soares

\section{Proto-História}

987 Produção de sal marinho na Idade do Bronze do noroeste Português. Alguns dados para uma reflexão

Ana M. S. Bettencourt / Sara Luz / Nuno Oliveira / Pedro P. Simões / Maria Isabel C. Alves / Emílio Abad-Vidal

1001 A estátua-menir do Pedrão ou de São Bartolomeu do Mar (Esposende, noroeste de Portugal) no contexto arqueológico da fachada costeira de entre os rios Neiva e Cávado Ana M. S. Bettencourt / Manuel Santos-Estévez / Pedro Pimenta Simões / Luís Gonçalves

1015 O Castro do Muro (Vandoma/Baltar, Paredes) - notas para uma biografia de ocupação da Idade do Bronze à Idade Média

Maria Antónia D. Silva / Ana M. S. Bettencourt / António Manuel S. P. Silva / Natália Félix

1031 Do Bronze Final à Idade Média - continuidades e hiatos na ocupação de Povoados em Oliveira de Azeméis João Tiago Tavares / Adriaan de Man

1041 As faunas do final da Idade do Bronze no Sul de Portugal: leituras desde o Outeiro do Circo (Beja)

Nelson J. Almeida / Íris Dias / Cleia Detry / Eduardo Porfírio / Miguel Serra

1055 A Espada do Monte das Oliveiras (Serpa) - uma arma do Bronze Pleno do Sudoeste Rui M. G. Monge Soares / Pedro Valério / Mariana Nabais / António M. Monge Soares

1065 São Julião da Branca (Albergaria-a-Velha) - Investigação e valorização de um povoado do Bronze Final

António Manuel S. P. Silva / Paulo A. P. Lemos / Sara Almeida e Silva / Edite Martins de Sá

1083 Do castro de S. João ao Mosteiro de Santa Clara: notícia de uma intervenção arqueológica, em Vila do Conde Rui Pinheiro 
1095 O castro de Ovil (Espinho), um quarto de século de investigação - resultados e questões em aberto

Jorge Fernando Salvador / António Manuel S. P. Silva

1111 O Castro de Salreu (Estarreja), um povoado proto-histórico no litoral do Entre Douro e Vouga

Sara Almeida e Silva / António Manuel S. P. Silva / Paulo A. P. Lemos / Edite Martins de Sá

1127 Castro de Nossa Senhora das Necessidades (Sernancelhe): uma primeira análise artefactual Telma Susana O. Ribeiro

${ }_{1141}$ A cividade de Bagunte. O estado atual da investigação Pedro Brochado de Almeida

1153 Zoomorfos na cerâmica da Idade do Ferro no NW Peninsular: inventário, cronologias e significado Nuno Oliveira / Cristina Seoane

1163 Vasos gregos em Portugal: diferentes maneiras de contar a história do intercâmbio cultural na Idade do Ferro

Daniela Ferreira

1175 Os exotica da necrópole da Idade do Ferro do Olival do Senhor dos Mártires (Alcácer do Sal) no seu contexto regional

Francisco B. Gomes

\section{Antiguidade Clássica e Tardia}

1191 O uso de madeira como combustível no sítio da Quinta de Crestelos (Baixo Sabor): da Idade do Ferro à Romanização Filipe Vaz / João Tereso / Sérgio Simões Pereira / José Sastre / Javier Larrazabal Galarza / Susana Cosme / José António Pereira / Israel Espi

1207 Cultivos de Época Romana no Baixo Sabor: continuidade em tempos de mudança? João Pedro Tereso / Sérgio Simões Pereira / Filipe Santos / Luís Seabra / Filipe Vaz

1221 A casa romana na Hispânia: aplicação dos modelos itálicos nas províncias ibéricas Fernanda Magalhães / Diego Machado / Manuela Martins

1235 As pinturas murais romanas da Rua General Sousa Machado, n. ${ }^{5}$ 1, Chaves José Carvalho

1243 Trás do Castelo (Vale de Mir, Pegarinhos, Alijó) - Uma exploração agrícola romana do Douro

Tony Silvino / Pedro Pereira

1255 A sequência de ocupação no quadrante sudeste de Bracara Augusta: as transformações de uma unidade doméstica Lara Fernandes / Manuela Martins

1263 Os Mosaicos com decoração geométrica e geométrico-vegetalista dos sítios arqueológicos da área do Conuentus Bracaraugustanus. Novas abordagens quanto à conservação, restauro, decoração e datação Maria de Fátima Abraços / Licínia Wrench

1277 “Casa Romana” do Castro de São Domingos (Cristelos, Lousada): Escavação, Estudo e Musealização Paulo André de P. Lemos

1291 A arqueobotânica no Castro de Guifões (Matosinhos, Noroeste de Portugal): O primeiro estudo carpológico

Luís Seabra / Andreia Arezes / Catarina Magalhães / José Varela / João Pedro Tereso 
1305 Um Horreum Augustano na Foz do Douro (Monte do Castelo de Gaia, Vila Nova de Gaia) Rui Ramos

1311 Ponderais romanos na Lusitânia: padrões, formas, materiais e contextos de utilização Diego Barrios Rodríguez

1323 Um almofariz centro-itálico na foz do Mondego

Marco Penajoia

1335 Estruturas romanas de Carnide - Lisboa Luísa Batalha / Mário Monteiro / Guilherme Cardoso

1347 O contexto funerário do sector da "necrópole NO" da Rua das Portas de S. Antão (Lisboa): o espaço, os artefactos, os indivíduos e a sua interconectividade na interpretação do passado Sílvia Loja, José Carlos Quaresma, Nelson Cabaço, Marina Lourenço, Sílvia Casimiro, Rodrigo Banha da Silva, Francisca Alves-Cardoso

${ }_{1361}$ Povoamento em época Romana na Amadora - resultados de um projeto pluridisciplinar Gisela Encarnação / Vanessa Dias

1371 A Arquitectura Residencial em Mirobriga (Santiago do Cacém): contributo a partir de um estudo de caso Filipe Sousa / Catarina Felício

${ }_{1385}$ O fim do ciclo. Saneamento e gestão de resíduos nos edifícios termais de Mirobriga (Santiago do Cacém)

Catarina Felício / Filipe Sousa

1399 Balsa, Topografia e Urbanismo de uma Cidade Portuária Vítor Silva Dias / João Pedro Bernardes / Celso Candeias / Cristina Tété Garcia

1413 No Largo das Mouras Velhas em Faro (2017): novas evidências da necrópole norte de Ossonoba e da sua ocupação medieval Ricardo Costeira da Silva / Paulo Botelho / Fernando Santos / Liliana Nunes

1429 Instrumentos de pesca recuperados numa fábrica de salga em Ossonoba (Faro) Inês Rasteiro / Ricardo Costeira da Silva / Paulo Botelho

1439 A Necrópole Romana do Eirô, Duas Igrejas (Penafiel): intervenção arqueológica de 2016 Laura Sousa / Teresa Soeiro

1457 Ritual, descarte ou afetividade? A presença de Canis lupus familiaris na Necrópole Noroeste de Olisipo (Lisboa)

Beatriz Calapez Santos / Sofia Simões Pereira / Rodrigo Banha da Silva / Sílvia Casimiro / Cleia Detry / Francisca Alves Cardoso

1467 Dinâmicas económicas em Bracara na Antiguidade Tardia Diego Machado / Manuela Martins / Fernanda Magalhães / Natália Botica

1479 Cerâmicas e Vidros da Antiguidade Tardia do Edifício sob a Igreja do Bom Jesus (Vila Nova de Gaia) Joaquim Filipe Ramos

1493 Novos contributos para a topografia histórica de Mértola no período romano e na Antiguidade Tardia Virgílio Lopes

\section{8. Época Medieval}

1511 Cerâmicas islâmicas no Garb setentrional "português": algumas evidências e incógnitas Constança dos Santos / Helena Catarino / Susana Gómez / Maria José Gonçalves / Isabel Inácio / Gonçalo Lopes / Jacinta Bugalhão / Sandra Cavaco / Jaquelina Covaneiro / Isabel Cristina Fernandes / Ana Sofia Gomes 
1525 Contributo para o conhecimento da cosmética islâmica, em Silves, durante a Idade Média Rosa Varela Gomes

1537 Yábura e o seu território - uma análise histórico-arqueológica de Évora entre os séculos VIII-XII José Rui Santos

1547 A encosta sul do Castelo de Palmela - resultados preliminares da escavação arqueológica Luís Filipe Pereira / Michelle Teixeira Santos

1559 A igreja de São Lourenço (Mouraria, Lisboa): um conjunto de silos e de cerâmica medieval islâmica

Andreia Filipa Moreira Rodrigues

1571 O registo material de movimentações populacionais no Médio Tejo, durante os séculos XII-XIII. Dois casos de "sunken featured buildings", nos concelhos de Cartaxo e Torres Novas Marco Liberato / Helena Santos / Nuno Santos

1585 O nordeste transmontano nos alvores da Idade média. Notas para reflexão Ana Maria da Costa Oliveira

1601 Sepulturas escavadas na rocha do Norte de Portugal e do Vale do Douro: primeiros resultados do Projecto SER-NPVD

Mário Jorge Barroca / César Guedes / Andreia Arezes / Ana Maria Oliveira

1619 "Portucalem Castrum Novum" entre o Mediterrâneo e o Atlântico: o estudo dos materiais cerâmicos alto-medievais do arqueossítio da rua de D. Hugo, nํ. 5 (Porto) João Luís Veloso

1627 A Alta Idade Média na fronteira de Lafões: notas preliminares sobre a Arqueologia no Concelho de Vouzela

Manuel Luís Real / Catarina Tente

1641 Um conjunto cerâmico medieval fora de portas: um breve testemunho aveirense Susana Temudo

${ }_{1651}$ Os Lóios do Porto: uma perspetiva integrada no panorama funerário da Baixa Idade Média à Época Moderna em meios urbanos em Portugal

Ana Lema Seabra

1659 O Caminho Português Interior de Santiago como eixo viário na Idade Média Pedro Azevedo

1665 Morfologia Urbana: Um exercício em torno do Castelo de Ourém André Donas-Botto / Jaqueline Pereira

1677 Intervenção arqueológica na Rua Marquês de Pombal/Largo do Espírito Santo (Bucelas, Loures)

Florbela Estêvão / Nathalie Antunes-Ferreira / Dário Ramos Neves / Inês Lisboa

1691 O Cemitério Medieval do Poço do Borratém e a espacialidade funerária na cidade de Lisboa Inês Belém / Vanessa Filipe / Vasco Noronha Vieira / Sónia Ferro / Rodrigo Banha da Silva

1705 Um Espaço Funerário Conventual do séc. XV em Lisboa: o caso do Convento de São Domingos da Cidade Sérgio Pedroso / Sílvia Casimiro / Rodrigo Banha da Silva / Francisca Alves Cardoso

\section{9. Época Moderna e Contemporânea}

1721 Arqueologia Moderna em Portugal: algumas reflexões críticas em torno da quantificação de conjuntos cerâmicos e suas inferências históricas e antropológicas Rodrigo Banha da Silva / André Bargão / Sara da Cruz Ferreira

1733 Faianças de dois contextos entre os finais do século XVI e XVIII do Palácio dos Condes de Penafiel, Lisboa

Martim Lopes / Tomás Mesquita 
1747 Um perfil de consumo do século XVIII na foz do Tejo: O caso do Mercado da Ribeira, Lisboa Sara da Cruz Ferreira / Rodrigo Banha da Silva / André Bargão

1761 Os Cachimbos dos Séculos XVII e XVIII do Palácio Mesquitela e Convento dos Inglesinhos (Lisboa)

Inês Simão / Marina Pinto / João Pimenta / Sara da Cruz Ferreira / André Bargão / Rodrigo Banha da Silva

1775 "Tomar os fumos da erua que chamão em Portugal erua sancta». Estudo de Cachimbos provenientes da Rua do Terreiro do Trigo, Lisboa

Miguel Martins de Sousa / José Pedro Henriques / Vanessa Galiza Filipe

1787 Cachimbos de Barro Caulínitico da Sé da Cidade Velha (República de Cabo Verde)

Rodrigo Banha da Silva / João Pimenta / Clementino Amaro

1801 Algumas considerações sobre espólio não cerâmico recuperado no Largo de Jesus (Lisboa) Carlos Boavida

1815 Adereços de vidro, dos séculos XVI-XVIII, procedentes do antigo Convento de Santana de Lisboa (anéis, braceletes e contas)

Joana Gonçalves / Rosa Varela Gomes / Mário Varela Gomes

1837 Da ostentação, luxo e poder à simplicidade do uso quotidiano: arqueologia e simbologia de joias e adornos da Idade Moderna Portuguesa Jéssica Iglésias

1849 Os amuletos em Portugal - dos objetos às superstições: o coral vermelho Alexandra Vieira

1865 Cerâmicas de Vila Franca de Xira nos séculos XV e XVI Eva Pires

1879 «Não passa por teu o que me pertence». Marcas de individualização associadas a faianças do Convento de Nossa Senhora de Aracoeli, Alcácer do Sal Catarina Parreira / Íris Fragoso / Miguel Martins de Sousa

1891 Cerâmica de Leiria: alguns focos de produção

Jaqueline Pereira / André Donas-Botto

1901 Os Fornos na Rua da Biquinha, em Óbidos Hugo Silva / Filipe Oliveira

1909 A casa de Pêro Fernandes, contador dos contos de D. Manuel I: o sítio arqueológico da Silha do Alferes, Seixal (século XVI) Mariana Nunes Ferreira

1921 O Alto da Vigia (Sintra) e a vigilância e defesa da costa Alexandre Gonçalves / Sandra Santos

1937 O contexto da torre sineira da Igreja de Santa Maria de Loures Paulo Calaveira / Martim Lopes

1949 A Necrópole do Hospital Militar do Castelo de São Jorge e as práticas funerárias na Lisboa de Época Moderna Susana Henriques / Liliana Matias de Carvalho / Ana Amarante / Sofia N. Wasterlain

1963 SAND - Sarilhos Grandes Entre dois Mundos: o adro da Igreja e a Paleobiologia dos ossos humanos recuperados

Paula Alves Pereira / Roger Lee Jesus / Bruno M. Magalhães

1975 Expansão urbana da vila de Cascais no século XVII e XVIII: a intervenção arqueológica na Rua da Vitória no 15 a 17

Tiago Pereira / Vanessa Filipe

1987 Novos dados para o conhecimento do Urbanismo de Faro em época Moderna Ana Rosa 
1995 Um exemplo de Arqueologia Urbana em Alcoutim: o Antigo Edifício dos CTT Marco Fernandes / Marta Dias / Alexandra Gradim / Virgílio Lopes / Susana Gómez Martínez

2007 Palácio dos Ferrazes (Rua das Flores/Rua da Vitória, Porto): a cocheira de Domingos Oliveira Maia

Francisco Raimundo

2021 As muitas vidas de um edifício urbano: História, Arqueologia e Antropologia no antigo Recreatório Paroquial de Penafiel Helena Bernardo / Jorge Sampaio / Marta Borges

2035 O convento de Nossa Senhora da Esperança de Ponta Delgada: o contributo da arqueologia para o conhecimento de um monumento identitário João Gonçalves Araújo / N’Zinga Oliveira

2047 Arqueologia na ilha do Corvo... em busca da capela de Nossa Senhora do Rosário Tânia Manuel Casimiro / José Luís Neto / Luís Borges / Pedro Parreira

2059 Perdidos à vista da Costa. Trabalhos arqueológicos subaquáticos na Barra do Tejo Jorge Freire / José Bettencourt / Augusto Salgado

2071 Arqueologia marítima em Cabo Verde: enquadramento e primeiros resultados do projecto CONCHA

José Bettencourt / Adilson Dias / Carlos Lima / Christelle Chouzenoux / Cristóvão Fonseca / Dúnia Pereira / Gonçalo Lopes / Inês Coelho / Jaylson Monteiro / José Lima / Maria Eugénia Alves / Patrícia Carvalho / Tiago Silva

2085 Trabalhos arqueológicos na Cidade Velha (Ribeira Grande de Santiago, Cabo Verde): reflexões sobre um projecto de investigação e divulgação patrimonial André Teixeira / Jaylson Monteiro / Mariana Mateus / Nireide Tavares / Cristovão Fonseca / Gonçalo C. Lopes / Joana Bento Torres / Dúnia Pereira / André Bargão / Aurélie Mayer / Bruno Zélie / Carlos Lima / Christelle Chouzenoux / Inês Henriques / Inês Pinto Coelho / José Lima / Patrícia Carvalho / Tiago Silva

2103 A antiga fortificação de Quelba / Khor Kalba (E.A.U.). Resultados de quatro campanhas de escavações, problemáticas e perspectivas futuras Rui Carita / Rosa Varela Gomes / Mário Varela Gomes / Kamyar Kamyad

2123 Colónias para homens novos: arqueologia da colonização agrária fascista no noroeste ibérico Xurxo Ayán Vila / José Mạ . Señorán Martín 


\title{
A NECRÓPOLE DO HOSPITAL MILITAR DO CASTELO DE SÃO JORGE E AS PRÁTICAS FUNERÁRIAS NA LISBOA DE ÉPOCA MODERNA
}

\author{
Susana Henriques ${ }^{1}$, Liliana Matias de Carvalho ${ }^{2}$, Ana Amarante ${ }^{3}$, Sofia N. Wasterlain ${ }^{2,3}$
}

RESUMO

A necrópole identificada na Rua do Recolhimento 7/9, Castelo de São Jorge (Lisboa, Portugal) corresponderá ao cemitério do Hospital Militar, localizado nas proximidades, activo entre os Séculos XVI e XVIII. Durante a escavação arqueológica foram identificadas sepulturas individuais, múltiplas, valas comuns e ossários. A organização espacial torna-se evidente em vários enterramentos, com a sobreposição de enterramentos que cortam os mais antigos, tendo sido observados esqueletos em decúbito dorsal, ventral e lateral (alguns contra paredes/ muros), nem sempre em conformidade com a regra canónica cristã.

Nesta necrópole da Idade Moderna existe uma grande variedade de práticas funerárias que refletem o tratamento da morte na moderna sociedade de Lisboa, transmitindo as suas preocupações sociais, culturais e religiosas. Simultaneamente, as práticas funerárias neste local tornaram-se uma ameaça à saúde pública, consequência da quantidade de corpos depositados num limitado espaço, físico e cronológico.

Palavras-chave: Época Moderna, Hospital Militar, Necrópole.

\section{ABSTRACT}

The necropolis found in Rua do Recolhimento 7/9, Castle of São Jorge, Lisbon, Portugal, corresponds to the military hospital cemetery, located nearby, in activity from the $16^{\text {th }}$ to the $18^{\text {th }}$ centuries. During the archaeological excavation both individual, multiple, and mass graves as well as ossuaries were identified. Space management becomes evident on several burials, mainly with overlap of other burials that end cutting the oldest ones, skeletons in supine, ventral and lateral position (and against walls), not always in conformity with the canonical Christian rules.

This post-medieval necropolis presents an array of funerary practices as a reflection of the Lisbon modern society, transmitting social, cultural and religious worries, becoming a public health issue due to the amount of bodies deposit in such a small space and in a short time.

Keywords: Post Medieval, Military Hospital, Necropolis.

"The cemetery can be seen as a long-lived parchment, in which the digging of new graves is a text laid on after only partial erasure of the older texts (earlier graves) creating an ever-changing palimpsest in which the new cannot entirely wipe away the old, and indeed may preserve the only evidence of the old."

Sian Anthony, 2015

\footnotetext{
1. EON-Indústrias Criativas; susana79henriques@gmail.com

2. University of Coimbra, Research Centre for Anthropology and Health, Department of Life Sciences, Calçada Martim de Freitas, 300o-456 Coimbra, Portugal

3. University of Coimbra, Centre for Functional Ecology, Department of Life Sciences, Calçada Martim de Freitas, 30oo-456 Coimbra, Portugal
} 


\section{INTRODUÇÃO}

Os rituais funerários afetam os mortos, mas acima de tudo refletem as necessidades dos vivos, na forma de lidar com o corpo e de salvar a alma do defunto, na gestão das limitações físicas do espaço funerário e os desafios do coveiro nas suas tarefas diárias (Anthony, 2015; Boyle, 2015; Johnson, 2008; Rugg, 200o; Souquet-Leroy et al., 2015; Worpole, 2003). Esta realidade é evidente na necrópole identificada na Rua do Recolhimento nำ 7/9 em Lisboa, Portugal. Os registos de óbito da Freguesia de Santa Cruz do Castelo fazem referência a duas necrópoles no Castelo de São Jorge, uma pertencente à Igreja Matriz de Santa Cruz, que se localizaria no adro do referido templo e, outra ao Hospital Militar (também referido como Hospital dos Soldados, Hospital do Castelo ou Hospital de São João de Deus), em atividade entre os séculos XVI e XVIII (Borges, 2007, p. 57). Os dados recolhidos durante a escavação arqueológica na Rua do Recolhimento, aqui descritos, referem-se à segunda necrópole (Figura 1).

O espaço funerário da Rua do Recolhimento apresenta uma área de cerca de $107 \mathrm{~m}^{2}$ escavados, de onde foram exumados 954 indivíduos, e está associado ao hospital/prisão (do castelo ou da "cadea nova desta freguesia" como aparece referenciado no livro de óbitos). Através da ocupação deste sítio, tanto em área como em profundidade, foi possível identificar várias práticas funerárias relacionadas com aspetos culturais, religiosos e de carácter prático. É, até ao momento e, em número de enterramentos a maior necrópole de soldados de época moderna associada a um Hospital Militar em Portugal.

\section{HOSPITAL MILITAR}

A primeira referência ao Hospital Militar no Castelo de São Jorge é de finais do século XVI, num documento que enuncia a entrada da Ordem de João de Deus no Hospital de S. Filipe e Santiago, sito no castelo de Lisboa a 4 de maio de 1592. Sendo assim, a presença de um hospital seria anterior a esta data (provavelmente 1580) e advém da necessidade de auxílio a marinheiros e soldados espanhóis ativos na conquista de Portugal (Borges, 2007, p. 57). Devido à sua relevância e à crescente importância dada aos cuidados médicos, foram feitas obras de expansão e melhoramento do edificado por decreto régio de 22 de maio de 166o (Borges, 2007, p. 94; Carreira, 2012), presididas pelos Irmãos Hospitaleiros de João de Deus.

Dentro da organização da instituição, que é um Hospital Militar gerido por uma ordem religiosa, o cemitério surge mais tarde (os defuntos dos hospitais seriam enterrados nos cemitérios paroquiais), sendo sempre referenciado que tinha de estar localizado perto do Hospital, paredes meias com o edificado ou num terreno escolhido só para essa função (Borges, 2007 , p. 48 e 227). No entanto, infelizmente, não foram identificadas até à data referências concretas sobre a data inicial de uso do espaço escavado, enquanto necrópole, associada ao Hospital dos Soldados. Uma escavação arqueológica de diagnóstico, dirigida pelas arqueólogas Ana Gomes e Alexandra Gaspar (Gaspar e Gomes, 2001), circunstanciada pela construção de um novo edifício, identificou as instalações do Hospital Militar no lado Sul da Rua do Recolhimento (em frente aos terrenos por nós intervencionados), com elementos arquitetónicos do século XVII, nomeadamente pisos, uma escadaria com degraus de madeira e uma parede revestida a azulejos, que levaria a um primeiro andar. Também foram registados elementos arquitetónicos do século XVI (por exemplo, uma cisterna) (Mestre, Gaspar e Gomes, 2002). Um dos compartimentos escavados foi interpretado como uma prisão, devido ao número elevado de cachimbos identificados, pelos elementos construtivos e grafítos das paredes (Gaspar e Gomes, 2005, p. 867). Estes achados apresentam-nos uma estrutura bem estabelecida no seio da comunidade, com um grande nível de organização e investimento arquitetónico, mostrando a importância do Hospital Militar instalado na área do castelo.

Entre 1640 e 1668, Portugal estava envolvido na Guerra da Restauração contra a Coroa de Reino de Castela, o que originou uma situação em que eram necessários hospitais militares (Borges 2007, p. 29). Contudo, este não esteve funcional durante um longo tempo, já que aquando do terramoto, o hospital ruiu, não sendo novamente erigido. Esta opção pode dever-se à mudança operada pela planificação pombalina da cidade de Lisboa, em que o Castelo perde influência face a uma cada vez mais marcante viragem para as margens ribeirinhas e Terreiro do Paço (Tavares, 2015). As escavações arqueológicas levadas a cabo por Gaspar e Gomes puseram em evidência sinais desta ocorrência, como pavimentos queimados e paredes estaladas que colapsaram. Os dados 
cronológicos (materiais e arquitetónicos) identificam um edificado que esteve em uso desde meados do século XVI até 1 de novembro de 1755 (Gaspar e Gomes, 2005, p. 868). Existe a possibilidade, evidenciada pelos trabalhos por nós conduzidos, de a necrópole em análise ter continuado a ser utilizada algum tempo após o terramoto, mesmo sem a presença física de um hospital militar, talvez como um espaço sepulcral de recurso uma vez que o cemitério da Igreja de Santa Cruz estaria sobrelotado com as vítimas do terramoto. Relembra-se que esta necrópole seria um espaço consagrado e por isso apto a receber enterramentos cristãos. Sabe-se que os militares que se encontravam internados no Hospital do Castelo de São Jorge e sobreviveram à catástrofe foram transferidos para o Hospital do Convento de São João de Deus na Pampulha (Carreira, 2012, p. 317).

A primeira referência ao Hospital dos Soldados no livro de óbitos da freguesia de Santa Cruz do Castelo é do ano de 1626, sendo curioso verificar que é denominado, em tal documentação, Hospital dos Castelhanos, referência ao facto de o Hospital ter sido criado durante a ocupação espanhola. Uma análise do livro de óbitos revela que o tratamento de pacientes não se limitava à população militar ativa, mas que se estendia também a uma parte da população prisional, como se pode constatar por este registo: "Aos quatro dias do mes de Abril de mil e setecentos e quarenta e outo annos faleceo no Hospital deste Castello com todos os sacramentos Manuel Ribeiro ou Antunes solteiro filho de Domingos Antunes já defunto, natural da freguesia de Sam Julião de Sarafoens termo de Guimaraens e faleceo no dito hospital por se achar prezo na cadea nova deste castello; não fez testamento está sepultado no somiterio do dito hospital de que fiz este assento dia era ut supra. O cura António Mauricio do Coutto." (www.tombo. pt: PT-ADLSB-PRQ-PLSB12-OO3-O3_mo358). A população de presidiários poderia assim ser também inumada na necrópole deste hospital, embora não se saiba se seria uma situação excecional ou recorrente. Os presos, na época, podiam ser criminosos que aguardavam uma sentença (inocência, degredo ou execução), os considerados loucos ou os vagabundos e mendigos (Sá, 2010). Verifica-se, contudo, através dos registos de óbitos, que nem todos os indivíduos que morriam no Hospital dos Soldados eram alvo de enterramento na necrópole adjacente.

O edifício do Hospital, no lado Sul da rua, parece relacionar-se com as extensões e melhoramentos orde- nados por $\mathrm{D}$. Afonso VI no já referido decreto régio de 166o (Borges, 2007, p. 94). As arqueológas responsáveis pelos trabalhos de escavação interpretam estas estruturas como um segundo hospital (Gaspar e Gomes, 2005, p. 866), considerando que o primeiro, datado de 1580 (Borges, 2007, p. 33 e 9o), estaria localizado noutra zona ainda por identificar, uma vez que não foram encontrados vestígios de uma estrutura anterior. Nesta mesma rua, mas no lado oposto ao Hospital escavado por Gaspar e Gomes, foi por nós identificada a necrópole que lhe corresponderia.

\section{NECRÓPOLE}

A necrópole está localizada no lado Norte da Rua do Recolhimento, defronte das estruturas principais identificadas como sendo do hospital. Este espaço sepulcral estaria delimitado por quatro paredes/muros e desenvolver-se-ia, à época, sobre elevadamente em relação à cota da rua.

A criação de uma área sepulcral instituiu-se através de novas realidades construtivas. Verificou-se durante os trabalhos arqueológicos que as escadas de acesso ao atual logradouro eram as mesmas escadas de acesso à necrópole. Estas escadas eram delimitadas pela parede fronteiriça com a rua e uma nova construção murária. Ao entrar neste espaço, com piso de baldosas dispostas em espinha, encontramo-nos imediatamente perante uma pintura mural, delimitada por um arco de tijoleira, inserido no novo muro. O corpo central deste painel exibe duas pinturas sobrepostas, executadas em momentos distintos. No estrato mais recente, evidenciam-se duas figuras de hábito negro apostadas no regaste de indivíduos, representados ladeados por labaredas. Esta representação remete para um imaginário associado ao Purgatório. Da campanha mais antiga, é visível nas zonas de descontinuidade da segunda, um resplendor que complementaria uma cruz de madeira, sendo ainda possível ver in situ os 4 encaixes metálicos que susteriam a cruz.

Atendendo à tipologia dos elementos pictóricos podemos balizar cronologicamente a estrutura entre os finais do século XVII e a primeira metade do século do XVIII, uma vez que os resplendores, elemento pertencente à campanha mais antiga, surgem, em termos de motivo artístico, na arte religiosa a partir do século XVII, banalizando-se, sobretudo ao nível da ourivesaria, a partir do século XVIII. As representações do Purgatório surgem a partir a $2^{\underline{a}}$ metade 
do século XVI (após Concílio de Trento) (Mendes, 2013, p. 35), sendo amplamente utilizadas na arte religiosa até aos séculos XIX e XX. Referimos, porém, que nesta representação as figuras de hábito negro podem ser interpretadas como sendo os monges da Ordem Hospitaleira de S. João de Deus, cujo hábito era caracterizado por uma túnica negra com capuz, determinado por Santo Agostinho nas "Regras. Constituições de la Ordem de Hospit.d de S. Juan de Dios”, em 1640, mas só aprovadas em 1741 (Borges, 2007, p. 293).

O painel, que pertenceria a um tipo de oratório, estava inserido no arco de tijolo e seria protegido por gradeamento, tendo-se verificado a existência de encaixes nas laterais e base do arco. Foram inclusivamente identificados elementos metálicos in situ, do possível gradeamento ou do seu encaixe no arco.

A escadaria da entrada terminava num degrau que denotava concavidades de encaixes de ferrolhos, onde também se denota a utilização pela abertura e fecho de um portão/porta. Esta porta ou portão dariam acesso a uma calçada de seixos delimitada por lajes de calcário dispostas na vertical.

A identificação de um oratório à entrada do cemitério do Hospital do Soldados fortalece, pela sua qualidade e imponência (seria visto da rua), a importância desta instituição no Castelo, e enunciava igualmente que este espaço era consagrado pela presença de uma pintura mural e de uma cruz (que relembramos não seria apenas uma representação mas também uma presença física, evidência corroborada pela presença de pregos): "The erection of a monument near the burial grounds of the event, as well as the presence of a cross, became the memory of the catastrophic episodes but not of the individuals affected by the epidemic" (Souquet-Leroy et al., 2015, p. 82), referem os autores para definir o que deveria ser o mínimo para a identificação de um local funerário consagrado, a cruz e, eventualmente, um pequeno monumento.

Podemos supor que a fase mais recente do mural, com a presença das figuras com o hábito hospitaleiro negro, ou seja, monges da ordem de São João de Deus, poderá estar relacionada com a canonização do mesmo a santo, no ano de 1691 (Borges, 2007, p. 99), afirmando e reivindicando desta forma aquele espaço.

A pintura enunciava a sacralização da área, já que um indivíduo, ao entrar no espaço, deparar-se-ia imediatamente, ao nível dos seus olhos, com a imagem do purgatório em que as figuras de túnica ne- gra estendem as mãos demonstrando visualmente a salvação das almas dos doentes que tinham morrido no hospital. A população teria assim conhecimento de que aquele espaço murado era um local sepulcral, uma comunicação por meio arquitetónico e imagético. Estamos perante a dicotomia do longe, mas próximo, de uma barreira física que protegia os mortos de serem perturbados pelos vivos e que igualmente isolava os vivos dos mortos (Rugg, 2000, p. 262).

A data de abandono do espaço funerário é incerta, mas, como referido, terá sido certamente após o terramoto de 1755. Nos anos que o precederam deu-se uma reorganização da cidade, sendo possível vislumbrar o mesmo na zona do Castelo de São Jorge. Note-se que a grande alteração nas práticas funerárias ocorreu, por força de lei estatal, apenas em 1835 , sendo uma consequência das ideias iluministas e de uma maior preocupação com a saúde pública (Carreira, 2012; Carvalho, 2012; França, 2008). A construção, posterior ao abandono, de uma nova estrutura habitacional civil, possivelmente datada de 1773 (como enuncia a placa que se encontra por cima da porta de entrada), sobre a área da necrópole afetou vários enterramentos. Esta afetação dos enterramentos reflete duas possibilidades: uma falta de conhecimento de que este espaço funcionou como necrópole, o que nos parece pouco plausível, ou a desconsideração desse fator (Figura 2).

Apesar da possibilidade do uso do espaço após 1755, a data de 1773, associada à construção do primeiro andar do edifício que aí se encontra hoje em dia, sela a utilização deste espaço enquanto necrópole. Será que a memória coletiva deste lugar como cemitério foi esquecida em tão curto espaço de tempo? Ou foi a tragédia do terramoto, um enorme marco mental, que forçou um novo paradigma urbanístico, com um design mais regular e as preocupações de salubridade como resultado da aplicação das teorias iluministas (Anthony, 2015; Boyle, 2015; Cabaço, 2009; Carreira, 2012; Carvalho, 2012; Johnson, 2008; Rugg, 2000; Tarlow, 2007, 2013; Worpole, 2003)? Parece que a decisão de não reconstruir o hospital do outro lado da rua levou ao abandono da necrópole militar nos anos seguintes.

A maior parte dos enterramentos da necrópole pertencem a indivíduos do sexo masculino com idades compreendidas entre os $12 \mathrm{e}$ os 50 anos. O mesmo padrão é observado nos ossários. Não foram identificadas lesões traumáticas ocorridas no momento de morte dos indivíduos (peri mortem) numa frequên- 
cia fora do comum, excluindo uma ligação direta com um teatro de guerra ou conflitos interpessoais. Por outro lado, foi registado um grande número de patologias infeciosas, desde sempre associadas a populações militares, o que vai de encontro a um hospital que servia toda a comunidade militar, para além das épocas de maior intensidade combativa (Ortner, 2003). Os indivíduos eram mais frequentemente enterrados em decúbito dorsal, mas também se identificaram deposições em decúbito ventral e lateral (geralmente contra paredes/muros de forma a maximizar o espaço) (Boyle, 2015; Souquet-Leroy et al., 2015). Durante a escavação arqueológica foram identificadas seis fases de utilização deste espaço, que correspondem a seis diferentes métodos de abordagem à gestão do espaço sepulcral.

Fase 1: A primeira fase foi identificada através de uma única sepultura estruturada, com orientação Oeste-Este, associada a uma pequena estrutura murária construída em duas fases e a um piso de terra batida. A sepultura foi construída com fragmentos de tijolo, tijoleira e calcário unidos por argamassa de cal. A sepultura exibe uma forma ovalada com $25 \mathrm{~cm}$ de profundidade sendo igualmente selada por argamassa da mesma tipologia. Infelizmente apenas o lado sul da sepultura se encontrava visível. Até agora não foi possível associar este enterramento ao Hospital Militar (Figura 3 e 4).

Fase 2: Foi efetuado um aterro de toda a área com sedimento de coloração amarela de forma a nivelar e sobrelevar a quota útil. É nesta área que se desenvolve a necrópole. Nesta fase identificaram-se vários enterramentos, seguindo a deposição canónica Oeste-Este, parecendo, no entanto, confinados à zona mais Oeste da área escavada.

Fase 3: Após o primeiro depósito foi efetuado um segundo aterro com um sedimento arenoso de coloração castanha-acinzentada. Os enterramentos desta fase caracterizam-se pela inumação em sepulturas múltiplas com 3 a 5 indivíduos, depositados com a cabeça e pés intercalados em orientações que poderiam ser Este-Oeste ou Oeste-Este. Identificou-se parco espólio em associação com os enterramentos desta fase, demonstrando a ausência de adornos/peças de vestuário, sugerindo que os corpos eram provavelmente enterrados despidos ou só com sudário (Muiznieks, 2015). As valas estavam alinhadas em fileiras que não se cortavam, sugerindo planeamento (Boyle, 2015; Souquet-Leroy et al., 2015) (Figura 5). Fase 4: Esta fase reflete a necessidade de conciliar um grande número de mortos com a saúde da comunidade (Carreira, 2012; Souquet-Leroy, 2015). É caracterizada por sepulturas duplas (cabeça-pés, lateral, um por cima do outro), em aparentes filas, maximizando o espaço. Devido a restrições impostas às partes anatómicas dos esqueletos e à identificação de alfinetes de bronze é de assumir que os corpos estavam envoltos num sudário (Souquet-Leroy, 2015). Mais uma vez, o planeamento está presente já que nenhuma das valas das sepulturas é cortada por outra, não afetando também as sepulturas da fase 3. Esta organização mostra um conhecimento da localização das sepulturas e uma preocupação de forma a não perturbar os mortos já inumados. As Fases 3 e 4 podem refletir duas crises mortuárias de curta duração. Estas crises de mortalidade eram comuns em Lisboa de época Moderna, já que a cidade ao mesmo tempo que dispunha de poucas condições sanitárias tinha uma abrangência global e recebia muitos mercadores e viajantes (e os seus vírus e bactérias) (Boyle, 2015; Carreira, 2012; Mitchell, 2015; Rodrigues, 1990; Souquet-Leroy et al., 2015; Tarlow, 2015) (Figura 6 e 7 ).

Fase 5: Esta fase reflete as normas, práticas culturais e religiosas da época, seguindo a deposição canónica Este-Oste/Oeste-Este, mas não o estrito Oeste-Este que surge noutras necrópoles cristãs (Souquet-Leroy, 2015). O pragmatismo encontra-se refletido na afetação parcial presente em quase todos os enterramentos (mas não o seu total levantamento), devido à necessidade de uso contínuo da área, onde novas valas cortavam as anteriores (Anthony, 2015). Uma vez que a área estava delimitada por muros e não permitia a expansão, outras soluções foram postas em prática pelos coveiros e pela administração do espaço sepulcral. Uma vala - carneiro - foi aberta (afetando vários enterramentos das Fase 3 e 4) com o propósito de reposicionar os ossos resultantes da abertura de novas sepulturas. Este ossário de grande dimensão tinha um número mínimo de indivíduos de 116 e terá sido utilizado durante toda a fase 5 . Esta é provavelmente a fase de utilização cronologicamente mais longa e a mais semelhante com as realidades dos cemitérios cristãos urbanos de época moderna (Anthony, 2015; Boyle, 2015; Souquet-Leroy et al., 2015) (Figura 8).

Fase 6: Na sua última fase, a memória da localização das sepulturas já era ténue (provavelmente já em fase de abandono deste cemitério pelas entidades militares/Irmãos Hospitaleiros de São João de Deus). Os enterramentos são menos numerosos, dispersos, 
com adultos junto a paredes (orientação Norte-Sul), e, pela primeira vez, três enterramentos infantis de idade muito jovem (dos 6 meses intrauterinos até aos 2 anos de idade). Esta utilização quase clandestina sugere a necessidade de enterramentos repentinos, podendo-se inferir a falta de espaço do cemitério da Igreja de Santa Cruz do Castelo ou a necessidade de esconder ou discriminar certos enterramentos (nados mortos/recém-nascidos). O ignorar da deposição canónica devido à urgência de enterrar é evidência de que o pragmatismo se sobrepôs ao aspeto religioso, uma característica das comunidades da era moderna, que iria terminar com os novos cemitérios ajardinados municipais de finais do século XVIII e século XIX (Anthony, 2015; Boyle, 2015; Jonhson, 2008; Rugg, 2000; Souquet-Leroy et al., 2015; Tarlow, 2007, 2013, 2015; Worpole, 2003) (Figura 9).

\section{PEQUENA NOTA SOBRE OS OSSÁRIOS}

Foram levantados vinte e três ossários, registando-se três tipos diferentes. O carneiro (NMI 116), com 4 metros de comprimento e provavelmente uma tampa removível (tábuas de madeira seriam suficientes). Devido ao seu uso constante seria essencial à gestão do espaço para a deposição dos ossos em espaço consagrado. No fundo do mesmo foi identificado uma camada de cal, provavelmente como acelerante para a decomposição. O uso da cal também foi identificado nas inumações (Figura 10).

O ossário 2 é de tamanho médio, com 2,10 m de comprimento e 1,20 m de largura, e um número mínimo de indivíduos de 32. Está relacionado com a construção do novo edifício civil que assentou em parte da necrópole (Este). A abertura de vala para construção de uma parede externa cortou vários enterramentos, sendo que posteriormente os ossos foram depostos ao lado da mesma vala, na zona exterior do novo edifício.

O ossário número 23 (NMI 10 a 14) também está relacionado com a construção do primeiro piso do edificado. Neste caso foi a construção das escadas interiores em cima da necrópole que cortou algumas sepulturas. Os trabalhadores terão decidido construir um nicho por baixo de um dos degraus, escondendo aí os ossos que tiveram mais significado para eles: crânios e os ossos longos das pernas.

Finalmente, os outros vinte ossários eram de pequena dimensão, a maior parte deles reduções, com um número mínimo de indivíduos variando entre 1 e 5 .

\section{DISCUSSÃO}

A não conformidade presente nas práticas de enterramento aponta para as realidades socioeconómicas vividas durante a era moderna. É razoável afirmar que o estudo dos rituais funerários é vital no conhecimento das práticas culturais de uma sociedade representando mais do que o simples "onde e como" são os mortos descartados (Fahlander e Oestigaard, 2008). A necrópole do Hospital Militar do castelo de São Jorge apresenta uma panóplia de soluções que refletem claramente as preocupações dos vivos.

A diversidade de sepulturas (múltiplas e duplas) pode estar associada a crises de mortalidade, comuns em Lisboa, devido a episódios epidémicos (Carreira, 2012, p. 37 e ss.; Rodrigues, 1990). As fontes históricas relatam vários períodos de crise desde finais do século XVI até ao XVIII, causadas por peste, febre tifoide, varíola ou tifo, muitas vezes aliadas a anos com más colheitas, resultando em escassez alimentar e inflação dos preços (Barbosa, 2001, p. 13; Carreira, 2012, p. 37 e ss.).

O uso intensivo do espaço sepulcral, com os enterramentos individuais, correspondente à quinta fase, mostra um hospital em pleno funcionamento, importante no cuidado aos militares, provavelmente associado com o crescimento da instituição no final do século XVII, e durante o século seguinte. Apesar de haver evidências do uso de caixões (pregos de ferro), a maior parte dos enterramentos terá sido feita diretamente no solo ou, eventualmente, com sudário. Num documento de 4 de Maio de 1645, o Alvará da entrega da administração dos Reais Hospitais Militares de Elvas, Campo Maior e Olivença aos Irmãos Hospitaleiros de S. João de Deus, é referido no capitulo 22: "As mortalhas dos defuntos e covas se tirará a despesa dos vestidos que levam os soldados para os Hospitais (...)” (Borges, 2017, p. 379 e 382).

Apesar do documento ser referente a hospitais da região alentejana, a sua gerência pertence aos Irmãos Hospitaleiros de São João de Deus, levando-nos a inferir que a realidade para o Hospital no Castelo de São Jorge não seria diferente, como ficou evidenciado pela posição das inumações e pela presença de alfinetes de bronze.

Podemos supor que a evidência dos alfinetes de sudário representa uma ritualização da forma de tratamento do morto, uma normalização. Este ato íntimo seria perpetuado pelos hospitaleiros de São João 
de Deus, podendo conter rituais como a lavagem do corpo e rezas (Inall e Lillie, 2020: 12).

Ainda pertencente à mesma cronologia (século XVII/XVIII) o Hospital de Ponte de Lima gerido pela Santa Casa indica que a responsabilidade do tratamento dos mortos recai sobre o casal de hospitaleiros, em que à hospitaleira cabia a função de amortalhar o defunto e ao hospitaleiro a de abrir a cova (Araújo, 214, 50 e 51). Esta menção aos trabalhadores civis de um hospital gerido por uma ordem religiosa é interessante e acaba por explicar a presença, diminuta é certa, de elementos do sexo feminino entre os indivíduos inumados.

Para uma cronologia pós-terramoto, com base em documentação de 1765 , sobre as Ordens que se devem observar num Hospital Militar, encontramos referência ao facto de que o lençol de um infetado passasse a servir de mortalha, de forma a não queimar o mesmo e assim o desperdiçar, não usando "nova grossaria em que se costumam amortalhar" (Borges, 2017, p. 386). É também sabido que quando ingressavam no hospital as pessoas eram despojadas de todos os seus objetos pessoais e vestuário (alvo de inventário à entrada) trocando-os por uma camisa do estabelecimento (Sá, 2010). Esta destituição de individualidade à entrada no hospital perpetua-se assim, segundo o que podemos observar, no tratamento funerário após a morte, já que se identificaram raros sinais de individualidade tanto no vestuário como no adorno (quase sempre de cariz religioso).

Verifica-se, pois, que seria prática normal o enterro em sudário para os defuntos dos hospitais militares e não só, sendo talvez a razão pela qual não foi possível até à data diferenciar os enterramentos dos soldados dos dos prisioneiros que tiveram assistência no hospital.

A organização espacial parece ter estado presente no planeamento desta necrópole de Época Moderna. Contudo, mostrando preocupações sociais, culturais e religiosas tornou-se um problema de saúde pública devido ao número de corpos depositados num espaço tão pequeno em tão curto espaço de tempo, o que comprometia a normal decomposição cadavérica (Anthony, 2015; Carreira, 2012, p. 38 e ss; Rodrigues, 1990). Um relatório de maio de 1694, no pico de uma crise epidémica, da autoria do Comendador-Mor da Saúde, Domingos Nogueira de Araújo, descreve que as doenças no Castelo estavam provavelmente relacionadas com os corpos, já à superfície, no cemitério do hospital militar, sendo uma situação grave de saúde pública (Andrade, 1954; Carreira, 2012, p. 38; Rodrigues, 1990).

\section{CONCLUSÃO}

Embora a disposição do corpo seja determinada por um ritual, neste caso a inumação, mostrando uma experiência cultural e religiosa feita pelos vivos, o corpo pode também constituir uma ameaça para os vivos (Anthony, 2015; Chapman, 2003; Fahlander e Oestigaard, 2008, p. 6). O funeral está imerso num ritual simbólico, mas também prático, que devido à falta de espaço levou à adoção de diferentes dinâmicas sociais, ignorando a ritualização convencional do enterro. A morte e os mortos são parte de um processo embebido num ambiente religioso, mas os aspetos sociais, culturais e económicos (aos quais se podem juntar os higiénicos/saúde pública) são tão ou mais importantes para a interpretação dos dados recolhidos.

Olhar o estudo de necrópoles com uma grelha analítica que privilegie a leitura integrada dos vários registos, fontes históricas, dados antropológicos e arqueológicos, permite o acesso a uma visão mais abrangente dos gestos e processos que levaram às práticas registadas.

Na Rua do Recolhimento, notou-se que, embora a necrópole se tenha iniciado seguindo uma ordem e gestão - muito militar até - esta foi abandonada, tal como a regra canónica, assim que foi necessário mais espaço para responder ao elevado grau de mortalidade registado no Hospital dos Soldados. Do mesmo modo, o sentido prático do iluminismo, o afastamento gradual da razão e da religião e a premência das regras de saúde pública devem ter levado ao abandono total desta necrópole considerada insalubre e o seu olvidamento sob uma construção civil (ainda assim de carácter popular como o atestam imagens da mesma datadas do século XIX).

\section{AGRADECIMENTOS}

As autoras gostariam de agradecer ao Centro de Investigação em Antropologia e Saúde, ao Centro de Ecologia Funcional è̀ EON - Industrias Criativas. A co-autora Liliana M. Carvalho foi financiada pela FCT - Fundação para a Ciência e Tecnologia, sob o projecto com a referência SFRH/BD//BIA/04004/2020. A co-autora Sofia N. Wasterlain foi financiada por fundos nacionais via FCT - Fundação para a Ciência 
e Tecnologia, sob o projecto com a referência FCT-PEst-OE/SADG/UIo283/2019.

\section{BIBLIOGRAFIA}

ANDRADE, F. de (1954) - A freguesia de Santa Cruz da Alcáçova de Lisboa.

ANTHONY, Sian (2015) - Hiding the body: ordering space and allowing manipulation of body parts within Modern cemeteries. The archeology of death in post-medieval Europe (Tarlow, S., ed.), pp. 170-188.

ARAÚJO, Ma . Marta Lobo de (2005) - Hospitais Reais. As freguesias do Distrito de Viana do Castelo na Memórias Paroquiais de 1758. Alto Minho: Memórias, História e Património, (Capela, José Viriato, coord.) Braga, Casa Museu de Monção/Universidade do Minho, pp. 651-652.

BARBOSA, Hermínia, e GODINHO Anabela (2001) - Crises de mortalidade em Portugal desde meados do século XVI até ao início do século XX. Universidade do Minho. Núcleo de Estudos de População e Sociedade (NEPS).

BORGES, Augusto José Moutinho (2007) - Os reais hospitais militares em Portugal administrados e fundados pelos Irmãos Hospitaleiros de S. João de Deus 1640-1834, Dissertação de doutoramento em História Das Ciências da Saúde. Faculdade de Ciências Médicas da Universidade Nova.

BOYLE, Angela (2015) - Approaches to post-medieval burial in England: past and present. The archeology of death in post-medieval Europe (Tarlow, S., ed.), pp. 39-6o.

CABAÇO, Patrícia Gonçalves (2009) - Cemitérios municipais de Lisboa: estratégias de articulação entre Thanatos $e$ Pólis. Dissertação de mestrado em arquitectura, Instituto Superior Técnico de Lisboa.

CARREIRA, Adélia Maria Caldas (2012) - Lisboa de 1731 a 1833: da desordem à ordem no espaço urbano. Dissertação de doutoramento em História de Arte. Faculdade de Humanidades e Ciências Sociais da Universidade Nova.

CARVAlHO, Hugo Pereira de (2012) - A inclusão do cemitério no espaço da cidade. Dissertação de mestrado para obtenção do grau em Arquitectura, Faculdade de Arquitectura, Universidade Técnica de Lisboa.

CHAPMAN, Robert (2003) - Death, society and archaeology: the social dimensions of mortuary practices. Mortality 8:3, pp. 305-312.

FAHLANDER, Fredrik, OESTIGAARD, Terje, eds. (2008) - The materiality of death: bodies, burials, beliefs. Oxford: Archaeopress.

FRANÇA, José Augusto (2008) - Lisboa: história fisica e moral. Horizonte.

GASPAR, A; GOMES, A. (2001) - Castelo de São Jorge Relatório das Escavações Arqueológicas.
MESTRE, V.; GASPAR, M.A.; GOMES, A.M. (2002) - Reabilitação do troço sul/nascente do caminho de ronda do castelo de São Jorge, Lisboa; in: Monumento - Revista Semestral de Edificios e Monumentos, nํ17, p. 132-139.

GASPAR, Alexandra e GOMES, Ana (2005) - O Hospital de São João de Deus no Castelo de São Jorge - Vestígios Arqueológicos. Actas do XVI Colóquio de História Militar - O Serviço de Saúde Militar nas comemoraçôes do IV centenário dos Irmão Hospitaleiros de São João de Deus em Portugal. pp. 863-889.

INALL, Y., e LILLIE, M. (2020) - Meaning and mnemonic in archaeological studies of death. Mortality, 25(1), pp.7-24.

MENDES, R. D. M. (2013) - A Devoção às Almas do Purgatório na Arte Azulejar de Coimbra Fé, Piedade e Emoção Estéti$c a$, dissertação de mestrado em história de Arte, Património e Turismo Cultural pela Universidade de Coimbra.

MESTRE, V.; GASPAR, M.A.; GOMES, A.M. (2002) - Reabilitação do troço sul/nascente do caminho de ronda do castelo de São Jorge, Lisboa; in: Monumento - Revista Semestral de Edificios e Monumentos, $\mathrm{n}^{\circ}$ 17, pp. 132-139.

MITCHELL, Piers D. ed. (2015) - Sanitation, Latrines and Intestinal Parasites in Past Populations. Ashgate.

MUIZNIEKS, Vitolds (2015) - The co-existence of two traditions in the territory of present-day Latvie in the $13^{\text {th }}-18^{\text {th }}$ centuries: burial in Dress and in a Shroud. The archeology of death in post-medieval Europe (Tarlow, S., ed.), pp. 88-110.

RODRIGUES, Teresa Ferreira (1990) - As Crises de Mortalidade em Lisboa (séculos XVI e XVII), Livros Horizonte.

RUGG, Julie (2000) - Defining the place of burial: what makes a cemetery a cemetery? Mortality 5:3, pp. 259-275.

SÁ, Isabel dos Guimarães (2010) - Os espaços de reclusão e a vida nas margens. História da Vida Privada em Portugal: a Idade Moderna (Monteiro, N.G., ed.).

SILVA, Augusto Vieira (1937) - O Castelo de S. Jorge em Lisboa: estudo histórico-descritivo. Emprêsa Nacional de Publicidade.

SOUQUET-LEROY, Isabelle, RÉVEILLAS, Hélène, e CASTEX, Dominique (2015) - The impact of epidemics on funerary practices in Modern France $\left(16^{\text {th }}-18^{\text {th }}\right.$ centuries). The archeology of death in post-medieval Europe (Tarlow, S., ed.), pp. 61-87.

TAVARES, Rui (2005) - O pequeno livro do grande terramoto. Tinta-da-China.

THARLOW, Sarah (2000) - Landscapes of memory: the nineteenth-century garden cemetery. European Journal of Archaeology, 3:2, pp. 217-239.

THARLOW, Sarah. (2007) - The archaeology of improvement in Britain, 1750-1850. Cambridge University Press.

WORPOLE, Ken (2003) - Last Landscapes: the architecture of the cemetery in the West. Reaktion Books. 


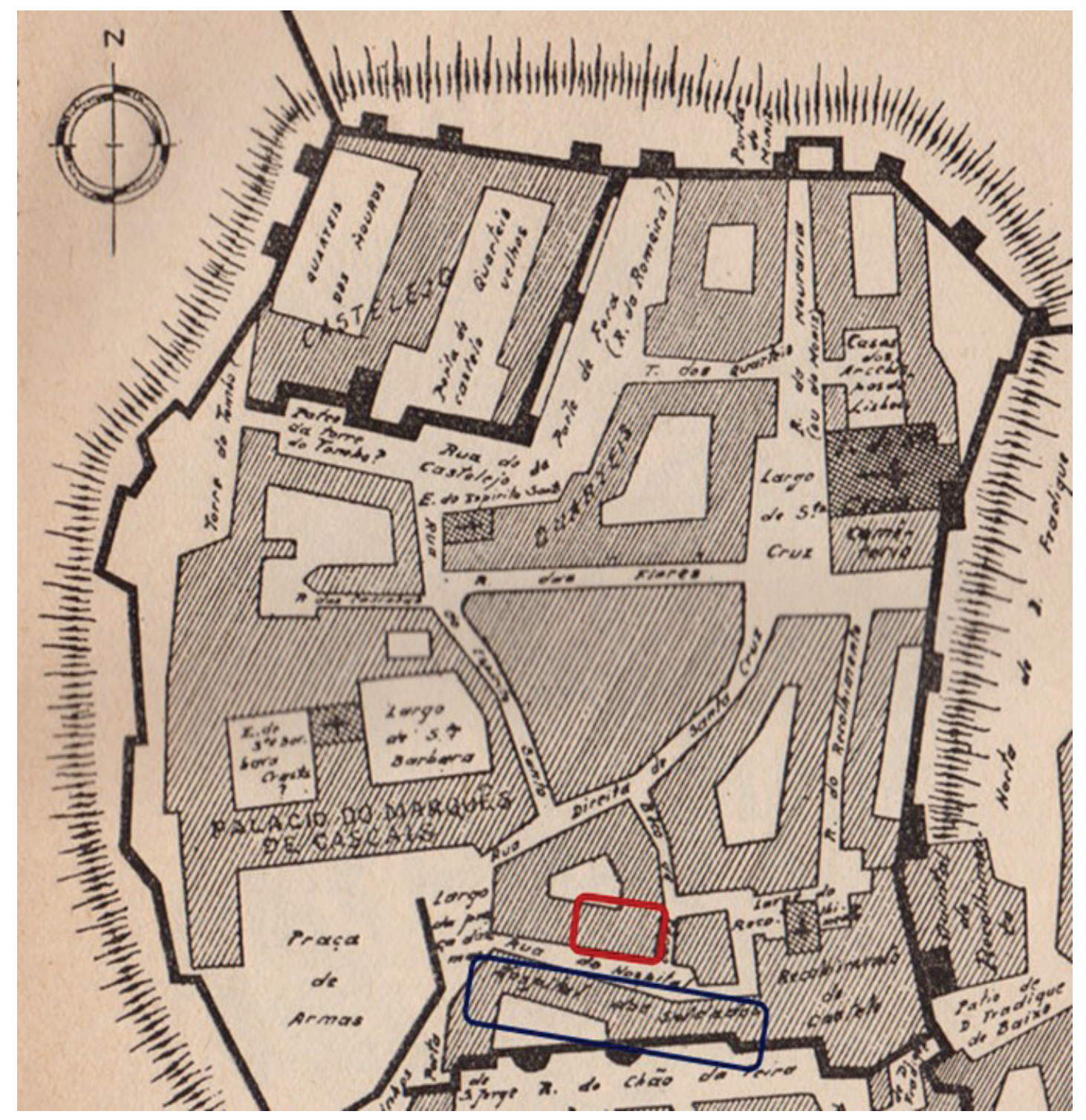

Figura 1 - Localização da necrópole (vermelho) e do Hospital Militar (Azul). In: Vieira da Silva (1937). O castelo de São Jorge em Lisboa, Lisboa, 2 edição. Página 2. 


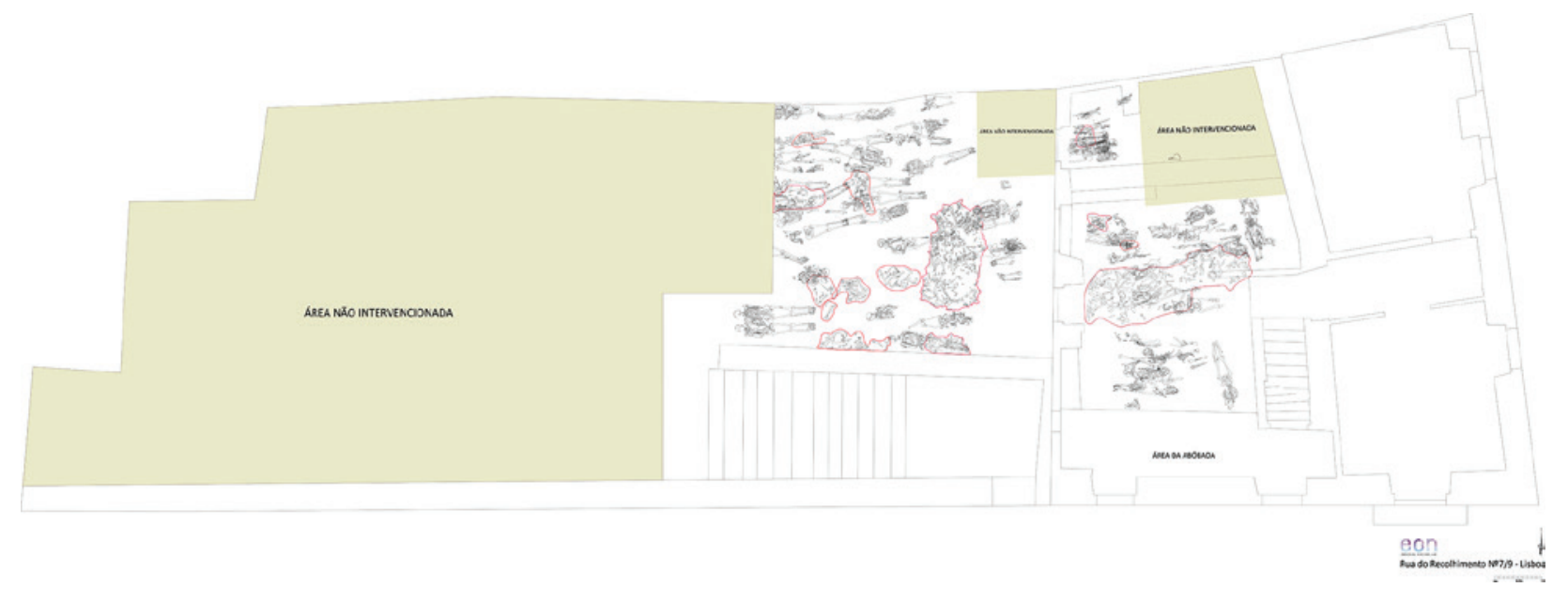

Figura 2-Plano compósito (primeira camada) mostrando a densidade e a afetação dos enterramentos. Desenho de Filipe Rebelo.

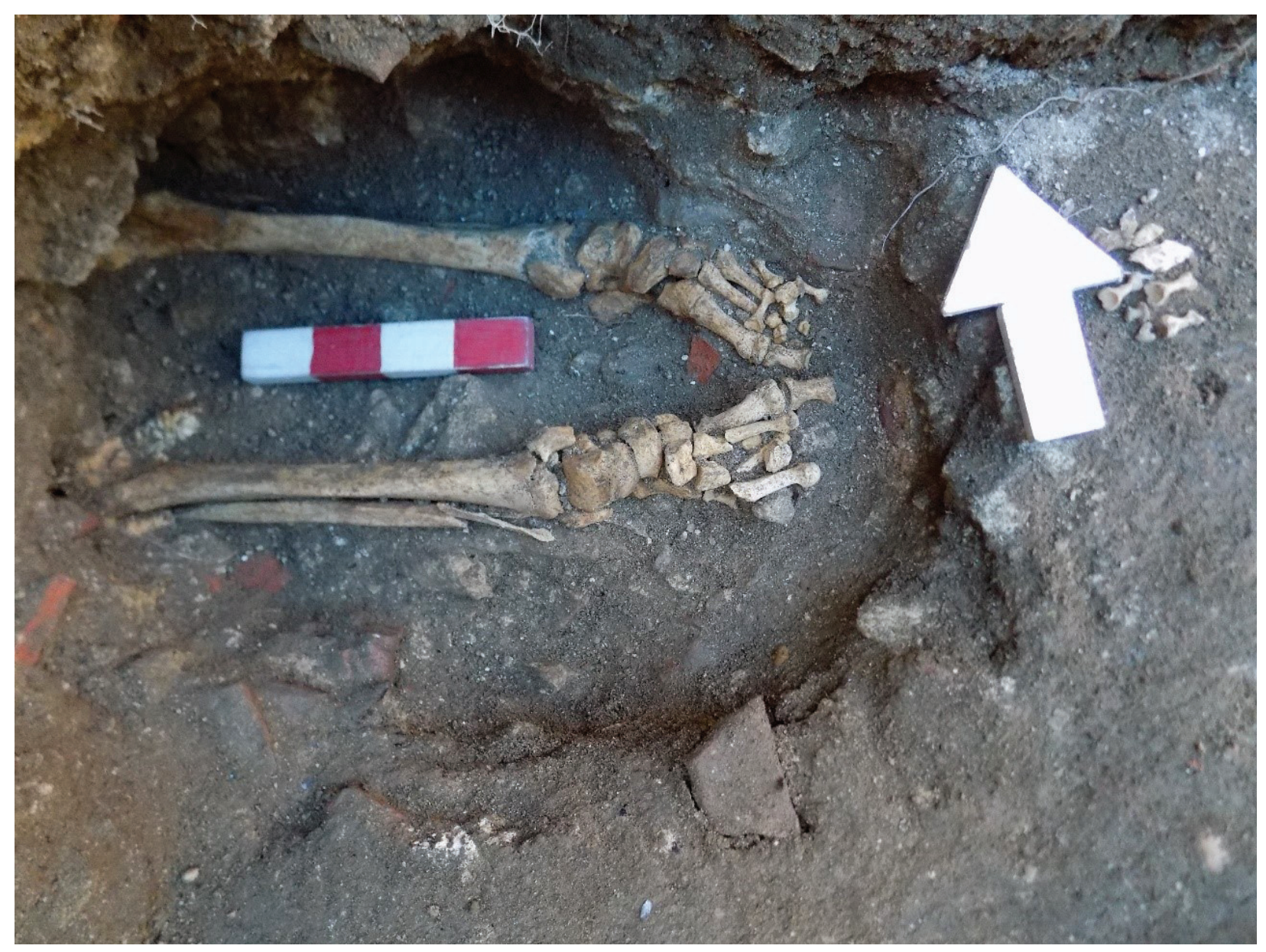

Figura 3 - Sepultura estruturada [Individuo 841]. Fase 1. 


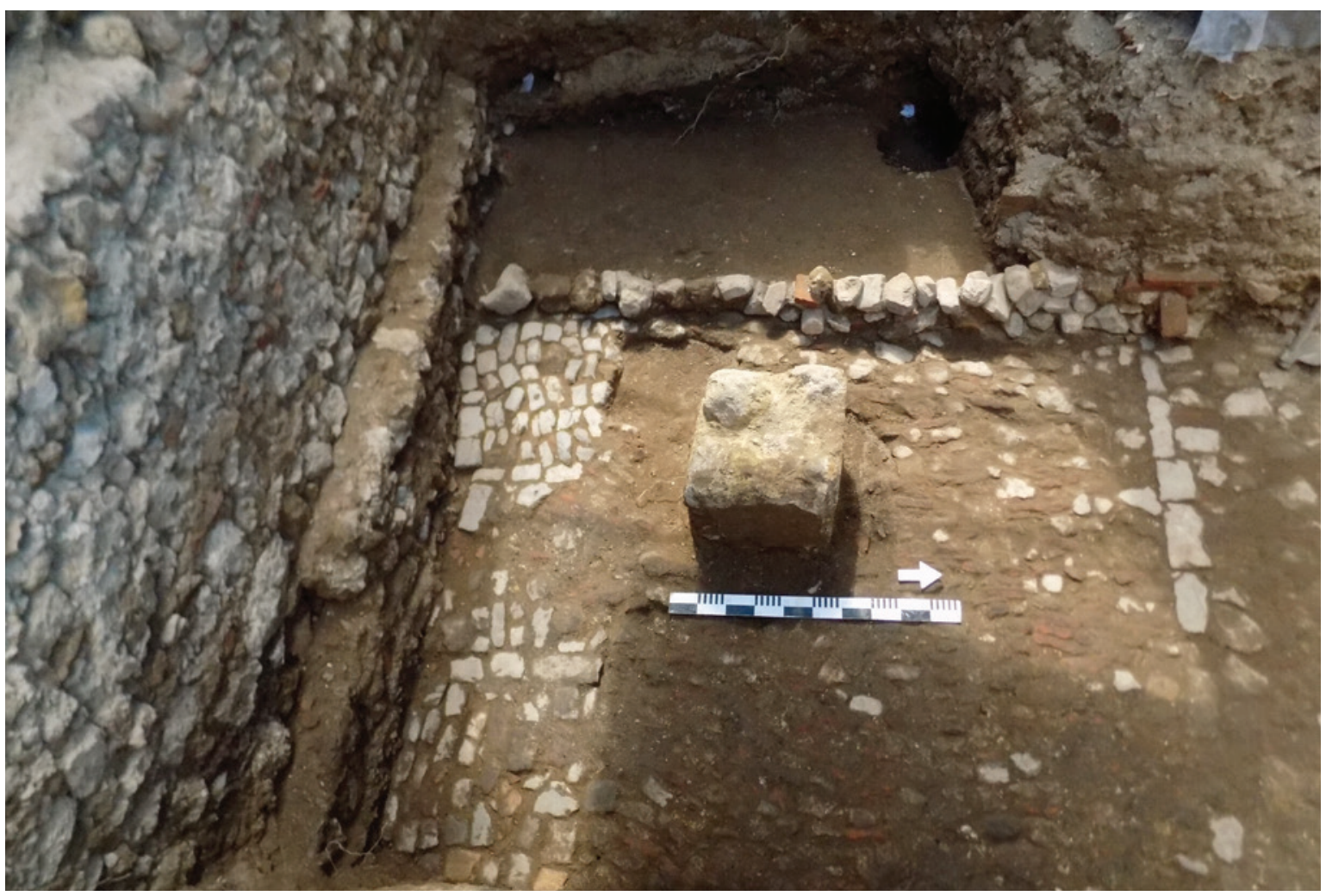

Figura 4 - Plano geral com a localização da sepultura, do piso de terra batida e dos muros que delimitam aquele espaço.

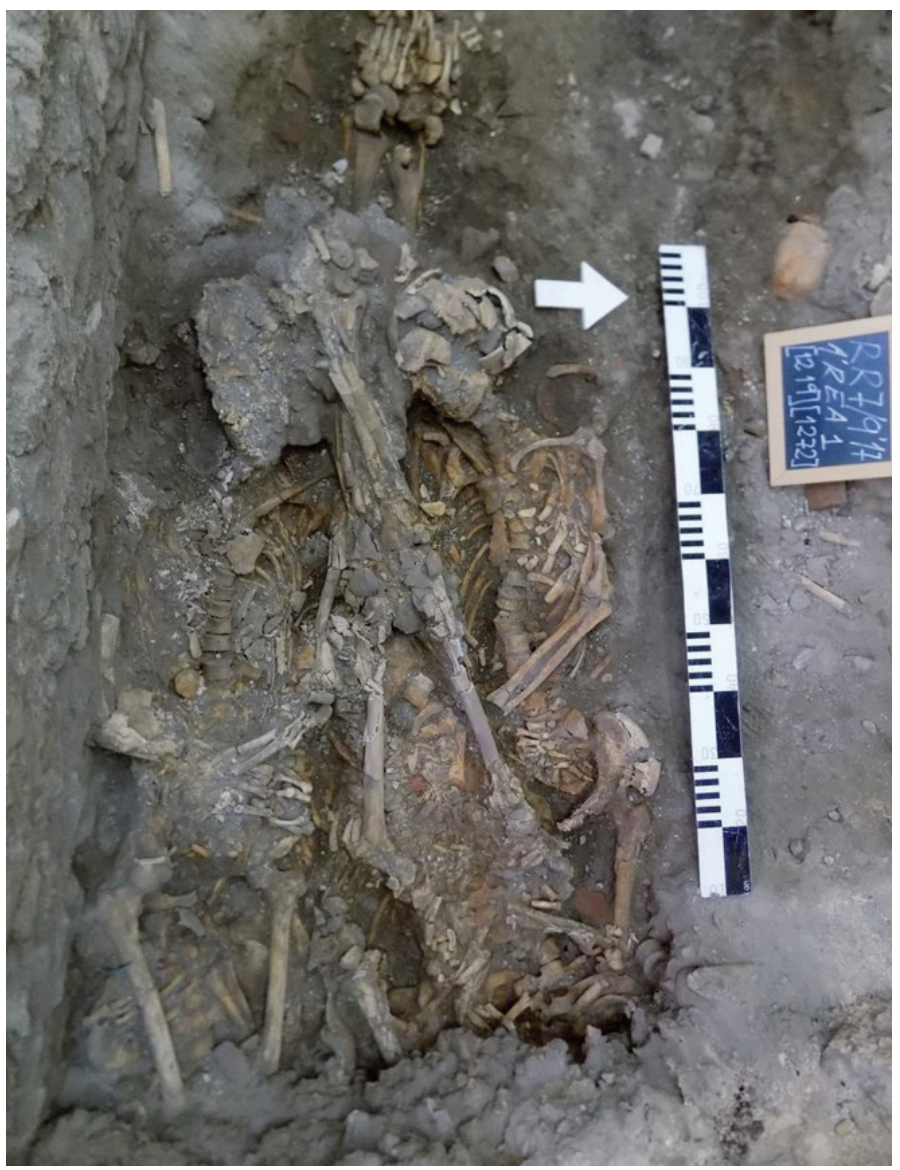

Figura 5-Sepultura múltipla, vala comum 1 (cinco indivíduos) Fase 3. 


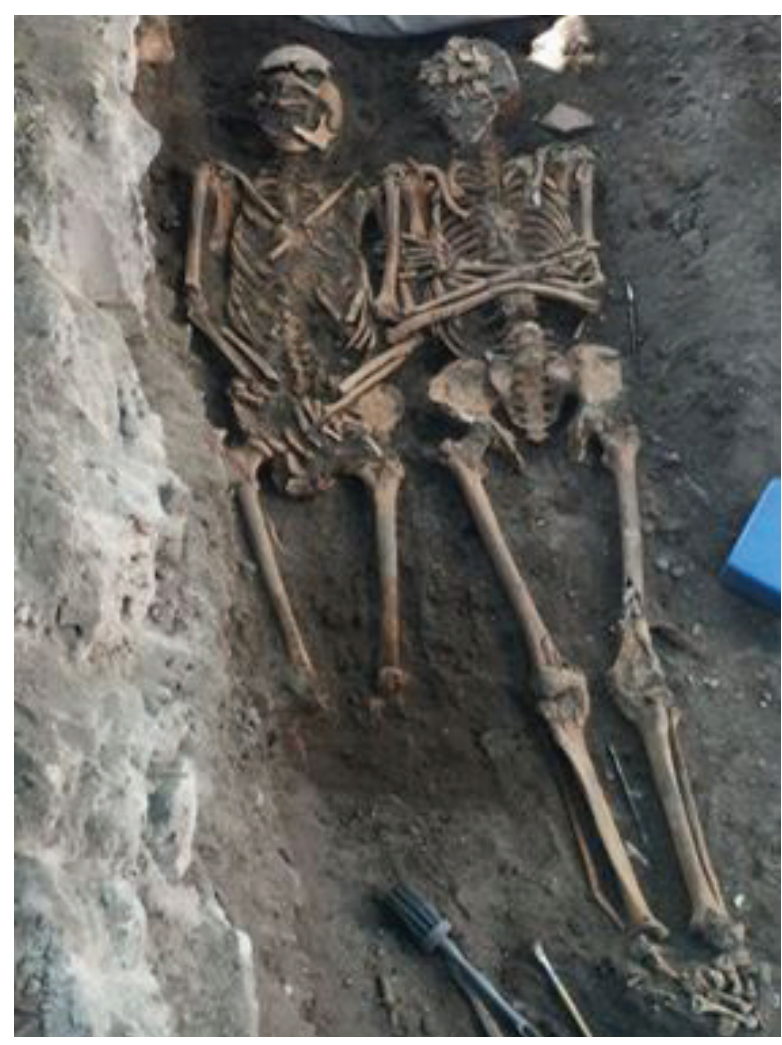

Figura 6 - Enterramento duplo [Indivíduos 18 e 19]. Fase 4.

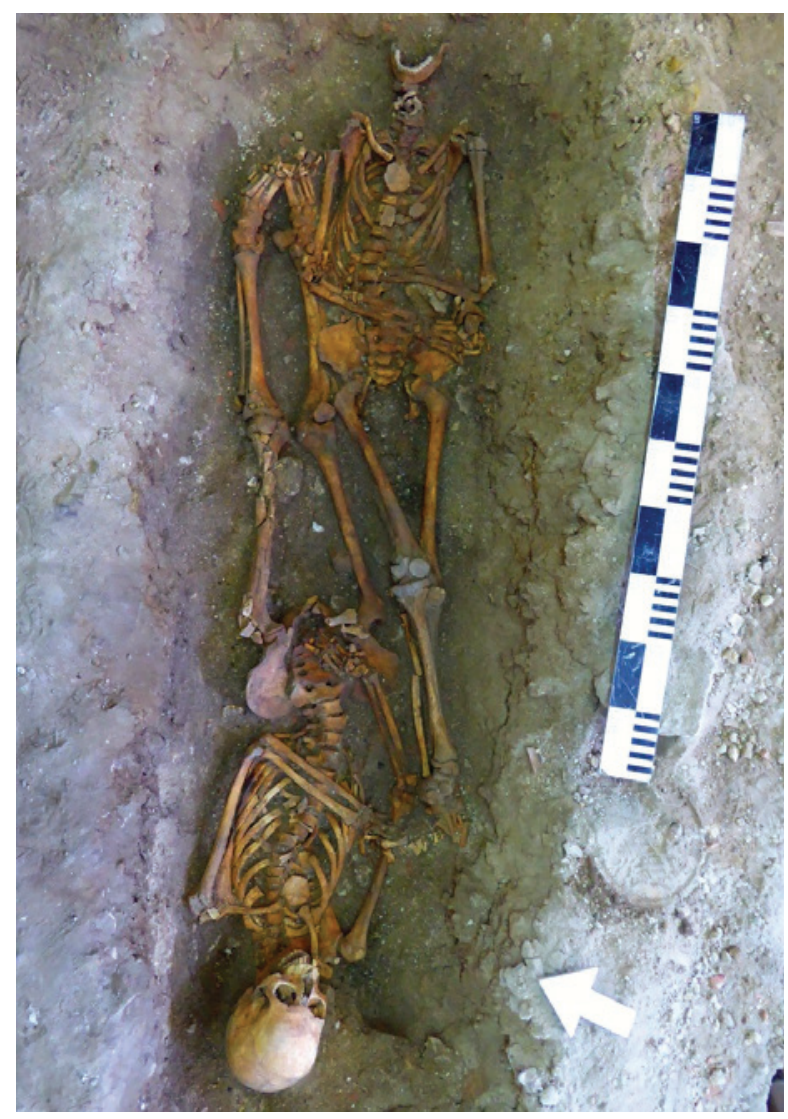

Figura 7-Sepultura dupla [Indivíduos 335 e 336]. Fase 4.

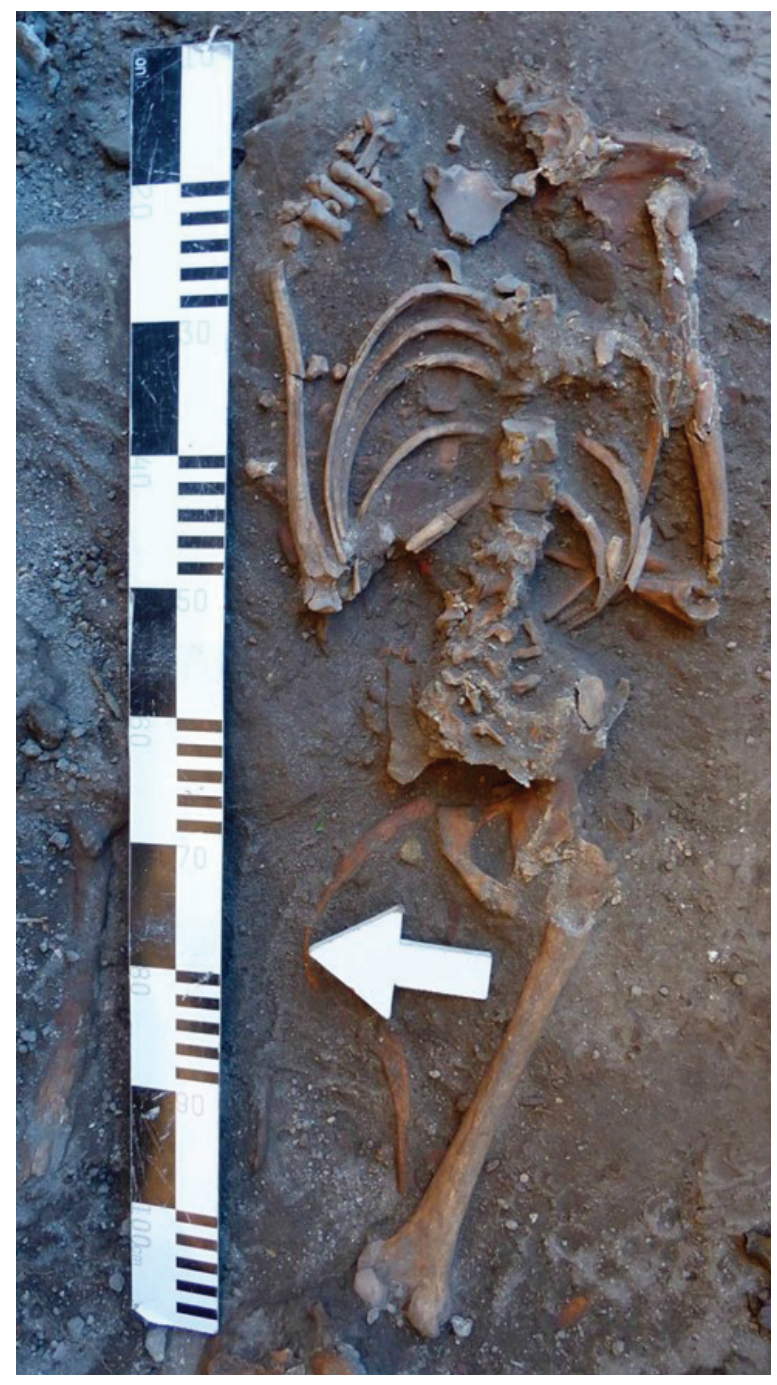

Figura 8 - Enterramento em decúbito ventral [Individuo 644]. Fase 5 . 


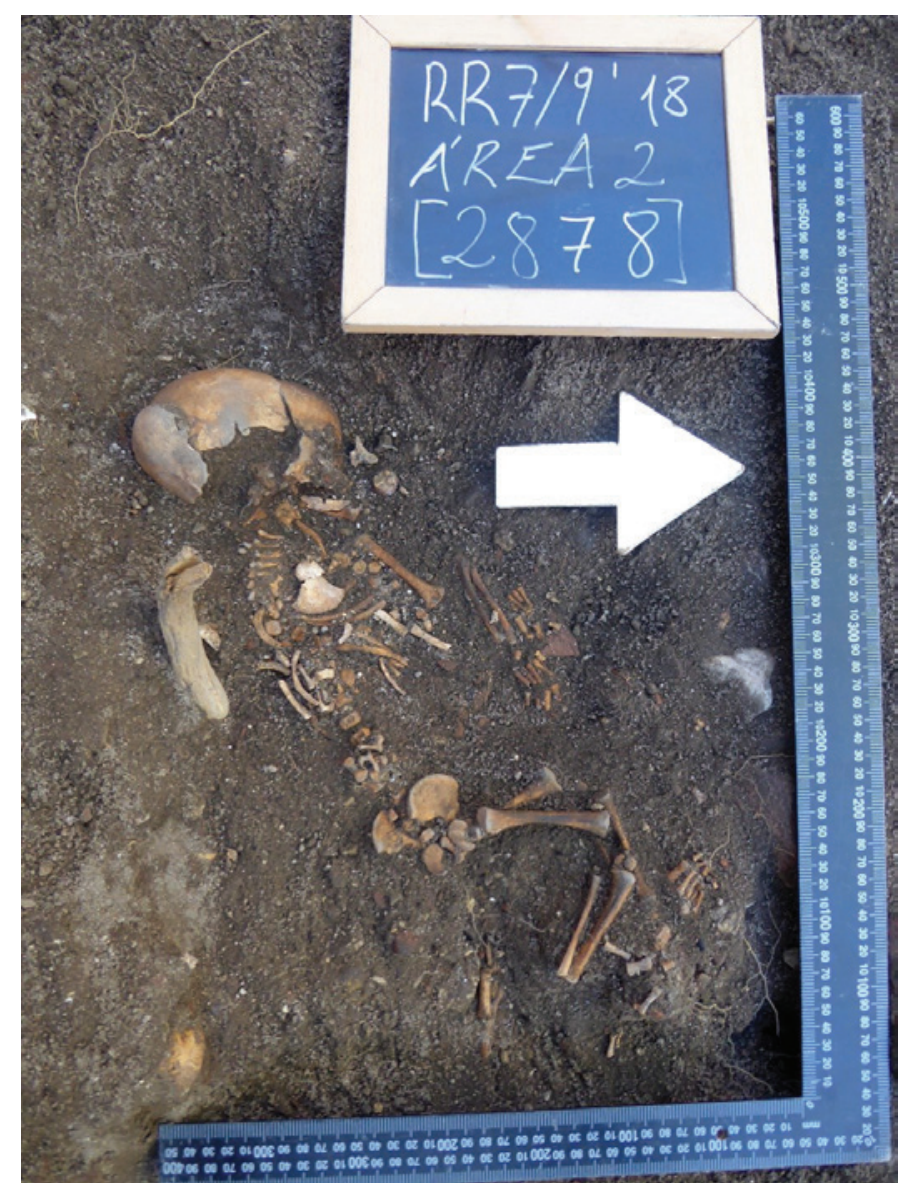

Figura 9 - [Individuo 620]. Fase 6.

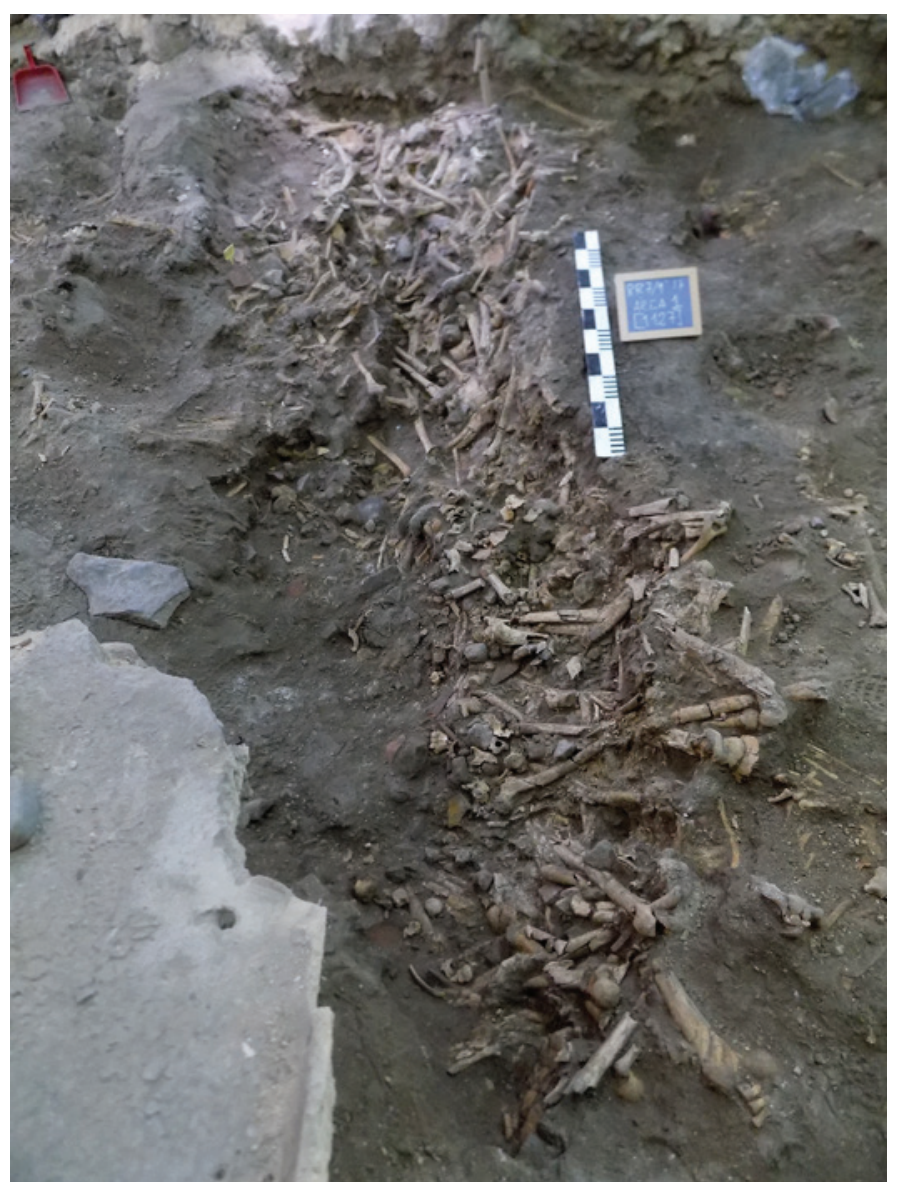

Figura 10 - Ossário 11/Carneiro. 


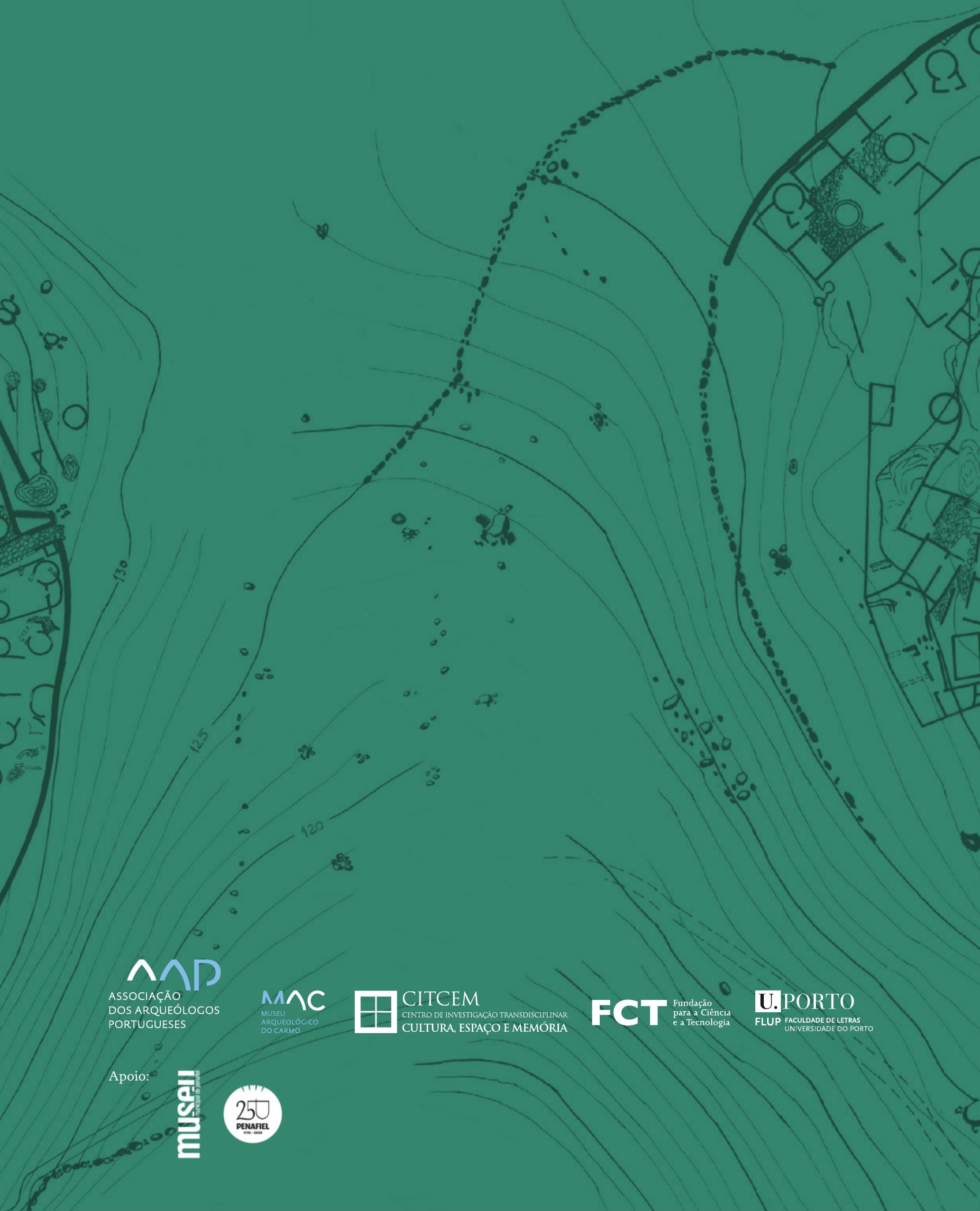

